\title{
The hazards of unconfined pyroclastic density currents: a new synthesis and classification according to their deposits, dynamics, and thermal and impact characteristics
}

Geoffrey A. Lernera,b, , Susanna F. Jenkinsa,b, Sylvain J. Charbonnierc, Jean-Christophe Komorowskid, Peter J. Baxtere

aEarth Observatory of Singapore, Nanyang Technological University, 50 Nanyang Avenue, Block N2-01a-15, Singapore 639798, Singapore

bAsian School of Environment, Nanyang Technological University, 62 Nanyang Dr, Singapore 637459, Singapore

cSchool of Geosciences, University of South Florida, 4202 E. Fowler Avenue, NES 107

Tampa, FL 33620-5550, USA

dEquipe de Géologie des Systèmes Volcaniques, Institut de Physique du Globe de Paris, Sorbonne Paris Cité, Université Paris Diderot, UMR CNRS 7154, 1, rue Jussieu, Paris 75238 Cedex 05, France eDepartment of Public Health and Primary Care, Institute of Public Health, University of Cambridge, Forvie Site, Robinson Way, Cambridge CB2 0SR, UK

*corresponding author: Geoffrey Lerner (geoffrey.lerner@ntu.edu.sg) (1)

(1)
This manuscript is a non-peer reviewed preprint submitted to Journal of Volcanology and Geothermal Research. Please note that the manuscript is currently under review and has not yet been accepted for publication. Subsequent versions of this manuscript may have different content. If accepted, the final version of this manuscript will be available via the 'Peer-reviewed Publication DOI' link on its EarthArXiv web page. Please feel free to contact me with any comments or feedback on our study.

\footnotetext{
Abstract

Pyroclastic density currents (PDCs) that escape their confining channels are among the most dangerous of volcanic hazards. These unconfined PDCs are capable of inundating inhabited areas that may be unprepared for these hazards, resulting in significant loss of life and damage to infrastructure. Despite their ability to cause serious impacts, unconfined PDCs have previously only been described for a limited number of specific case studies. Here, we carry out a broader comparative study that
} 
reviews the different types of unconfined PDCs, their deposits, dynamics and impacts, as well as the relationships between each element. Unconfined PDCs exist within a range of concentration, velocity and temperature: characteristics that are important in determining their impact. We define four endmember unconfined PDCs: 1. fast overspill flows, 2. slow overspill flows, 3. high-energy surges, and 4. low-energy detached surges (LEDS), and review characteristics and incidents of each from historical eruptions. These four end-members were all observed within the 2010 eruptive sequence of Merapi, Indonesia. We use this well-studied eruption as a case study, in particular the villages of Bakalan, $13 \mathrm{~km}$ south, and Bronggang $14 \mathrm{~km}$ south of the volcano, which were impacted by slow overspill flows and LEDS, respectively. These two unconfined PDC types are the least described from previous eruptions, but during the Merapi eruption the overspill flow resulted in building destruction and the LEDS in significant loss of life. We discuss the dynamics and deposits of these unconfined PDCs, and the resultant impacts. We then use the lessons learned from the 2010 Merapi eruption to assess some of the impacts associated with the deadly 2018 Fuego, Guatemala eruption. Satellite imagery and media images supplementing fieldwork were used to determine the presence of both overspill flows and LEDS, which resulted in the loss of hundreds of lives and the destruction of hundreds of buildings in inundated areas within $9 \mathrm{~km}$ of the summit. By cataloguing unconfined PDC characteristics, dynamics and impacts, we aim to highlight the importance and value of accounting for such phenomena in emergency management and planning at active volcanoes.

Keywords: volcano, pyroclastic flow, pyroclastic surge, Merapi, Fuego

\section{Introduction}

Pyroclastic density currents (PDCs) are the deadliest volcanic hazard, accounting for nearly a third of all historical volcano-related fatalities (Brown et al. 2017). They are also some of the most complex and unpredictable volcanic phenomena, which makes accurate forecasting of their occurrence, characteristics and the area impacted difficult. In particular, the ability for PDCs to surmount topography and travel outside of river valleys can place them in direct contact with communities on the flanks of volcanoes. They can destroy whole towns and kill tens of thousands of people (e.g., St Pierre, Martinique, 1902: Lacroix, 1904) but little is known about their internal dynamic processes, and the ability to measure their dynamics in real time during eruptions does not yet exist. As a result, they pose a significant challenge for emergency management planning at explosive volcanoes in densely populated regions. 
PDCs are gravity-driven mixtures of hot gases and fragmented particles (ranging from ash through lapilli to blocks and boulders). The term PDC encompasses a wide spectrum of densities and generation mechanisms, within which lie the two end-members of pyroclastic flow (dense, high particle concentration) and surge (dilute, low particle concentration) (Cole et al., 2015). A single PDC is commonly composed of two distinct layers - the denser, gravity driven basal "flow" layer and a more dilute, buoyant upper "surge" layer (Fisher 1995). While these layers can flow in unison under certain conditions (e.g., coupled PDCs in the 2015 eruption at Colima, Mexico; Pensa et al. 2019), it is common that they behave independently of each other, with the upper and lower layers moving at different speeds and having different characteristics (Breard and Lube 2017). The dense basal layer of a PDC (the flow) is topographically constrained so that their path typically remains confined to within a pre-existing channel, while the dilute, upper layer of PDCs (the surge) is less topographically constrained. Models of PDC transport regimes are improving in their sophistication, with the newest conceptual models including an intermediate flow layer between the dense basal and upper dilute layers (Lube et al., 2020). From a hazards perspective, this is extremely important, as it means the dilute, upper layer can detach from the lower, gravity driven flow, climbing topographic barriers and travelling to places that the rest of the PDC cannot (e.g., Nakada and Fujii 1993, Loughlin et al. 2002a,b, Dufek et al. 2015, Jenkins et al. 2016). As a result, surges can unexpectedly inundate built areas outside of pre-existing channels, where people are present.

Here we present new detailed data connecting the geology and dynamics of the distal $(>10 \mathrm{~km}) 5$ November 2010 unconfined PDCs at Merapi, focussing on their deposit characteristics, generation mechanisms and impacts to buildings, vegetation and victims, who were caught in the process of evacuating. We then use lessons drawn from the analysis of the Merapi 2010 eruption to assess PDC dynamics and impacts from the deadly June 2018 eruption of Volcán de Fuego in Guatemala. Using the same techniques as for Merapi 2010, we use satellite and media images to investigate loss of life and damage to structures caused by unconfined PDCs, supplemented by field studies focused on the deposits, and infer their types and dynamics. Data from both these eruptions provide an empirical foundation for better understanding and forecasting the impacts of unconfined PDCs on communities, highlighting the importance of accounting for the potential for such PDCs in emergency management planning, even where geological evidence of the PDCs is not preserved.

\subsection{Unconfined PDCs}

Several recorded volcanic tragedies in the past two centuries have resulted from surges that detached from their parent flows and inundated populated areas. While the upper more buoyant 
surge layer is more likely to be unconfined by channel topography, and thus able to inundate a wider range of areas than the dense basal layer, dense flows can also become unconfined during their propagation. Such 'unconfining' of the flow and/or surge typically results from a change in the underlying syn-eruptive topography or by an increase of the local mass flux, volume or velocity of the dense flow, which can act to reduce channel capacity or redirect the flow away from the primary channel direction. These topographic changes can be natural or the result of human intervention, and there are broadly three topographic-related mechanisms that can caused a PDC to become unconfined:

1. Lateral channel constriction: narrowing of the channel in which a PDC is confined reduces the cross-sectional area available and may cause PDCs to expand vertically, making it easier for the PDC to escape the channel (e.g., Merapi 1994 and 2006). Such constrictions can be the result of natural topographic changes (through erosion and deposition) or concrete channel confinement for lahars (e.g., sabo dams);

2. Vertical channel constriction: shallowing of a channel or prior infilling by deposits will similarly have the effect of reducing the volumetric capacity of the channel and thus promoting the overspill of confined PDCs. Sediment retention dams intended to constrain the flow of lahars can promote this (e.g., Merapi 2010);

3. Channel bends or obstructions: Sudden changes in the direction of the confined flow path of a PDC can promote flow overspill or surge detachment, especially in combination with any of the above factors, as the PDC retains straight-line momentum (e.g., Soufrière Hills, June 1997);

PDC overspill and detachment are more likely when a channel is near capacity, for example through previous infilling from confined PDCs, which reduces the height difference between valley base and top (Lube et al., 2011, Charbonnier et al., 2013). This can be exacerbated by the pulsating behaviour of PDCs in some eruptions, in which flows from repeated pulses of eruption can progressively infill the channel (Sulpizio and Dellino, 2008). Unsteady flow conditions and increases in flow characteristics such as velocity, thickness, and volume may promote overspilling (Charbonnier et al., 2013). Unrelated to channel topography, a fourth mechanism can also cause flows and/or surges to be unconfined:

4. Directed eruption: Eruptions that begin from an explosive eruption that projects energy laterally, rather than as a result of dome or column collapse into channels, will often cause the ensuing PDCs to be unconfined from their point of inception (e.g., Mt. St. Helens 1980). 


\subsection{PDC impacts}

The damage to communities caused by unconfined PDCs varies as a function of the PDC concentration, velocity, temperature, as well as other characteristics such as the transport of large clasts and debris that can act as missiles. For example, flow overspill typically causes impact through a combination of dynamic pressure, burial under metres of deposit, and/or thermal impact from temperatures that can reach over $800{ }^{\circ} \mathrm{C}$ (Cole et al., 2015), with near binary loss of life or infrastructure. By contrast, surge detachment can cause little physical damage because of low dynamic pressures and very thin (centimetres) remaining deposits, but their thermal impact can still cause casualties and indirect damage through fire (e.g., Baxter et al., 2005, Jenkins et al., 2013; Baxter et al., 2017). The dynamic characteristics of unconfined PDCs, and therefore the type and severity of impacts sustained, vary greatly depending on the generation mechanism and travel path of the PDC, as well as the mechanism through which overspill or detachment occurs. As a result, forecasting the occurrence and impacts associated with unconfined PDCs, across time and space, remains very challenging. Data for better understanding, and therefore forecasting, such events typically arise from field data, numerical modelling (e.g., Valentine and Wohletz, 1989, Neri et al., 2003, Esposti Ongaro et al., 2012, Benage et al., 2016) and/or large-scale experiments (e.g., Dellino et al., 2010, Lube et al., 2015, Brosch and Lube, 2020). Here, we focus on the value of the first: empirical observations and measurements, and how they can be supplemented with remote observations.

Despite their ability to cause serious impacts, unconfined PDCs have been previously described on a limited number of occasions, often tied to specific case studies in notable eruption sequences (e.g., Soufrière Hills 1997). The lack of a broader comparative study of the different types of unconfined PDCs, and the relationships between their occurrence, deposits, dynamics and the impacts they cause, leaves a gap in the literature that we aim to fill with this study. We review the physical characteristics and devastating impacts associated with unconfined PDCs and provide new geological, impact and casualty data on a subset of these unconfined PDCs - slow overspill flows and low-energy detached surges during the Merapi 2010 eruption, Indonesia. We focus on these two types of unconfined PDC as their impacts are not necessarily binary, i.e. buildings, infrastructure and vegetation may be damaged but not destroyed, and probabilities of survival or escape may be higher than for the higher-energy flows and surges. Low-energy, detached surges have been welldocumented in only two previous cases: the 1997 eruption of Soufrière Hills Volcano, Montserrat (Loughlin et al. 2002a, 2002b), and the 1994 eruption of Merapi, Indonesia (Abdurachman et al. 2000; Voight et al., 2000). The Merapi 2010 eruption provides a particularly relevant case study as it 
157 involved a wide variety of unconfined PDC types over the course of its eruptive sequence

158 (Charbonnier et al., 2013, Cronin et al., 2013, Komorowski et al., 2013, Jenkins et al., 2016). This

159 included significant impacts related to low-energy detached surges for which deposits were only 160 centimetres thick and therefore unlikely to be preserved in the geological record. The events 161 involving such detached surges and channel overspill flows during the 2010 Merapi eruption are 162 summarised in Komorowski et al. (2013), Cronin et al. (2013), Charbonnier et al. (2013), Jenkins et 163 al. $(2013,2016)$, and Baxter et al. (2017).

\section{Types of Unconfined PDCs}

Unconfined PDCs can be categorized by two main characteristics: their concentration and their velocity (Figure 1). The full spectrum of unconfined PDCs can be plotted within this matrix, with the following four end-member types as follows:

- Fast overspill flows (high-velocity/high-concentration) - spillout that occurs when a fast-moving, dense, channel-confined PDC is no longer constrained by a channel and invades adjacent areas;

- Slow overspill flows (low-velocity/high-concentration) - a dense, unconfined PDC that is moving at low speed, including the margin of a dense unconfined PDC that has slowed considerably from the speed of its confined parent flow;

- High-energy surges (high-velocity/low-concentration) - a dilute, directed PDC often stemming from a dome explosion that is typically unconfined from its inception;

- Low-energy detached surges (low-velocity/low-concentration) - the dilute, upper portion of a PDC that has decoupled from its denser basal parent flow, allowing it to travel to and invade areas not reached by the denser flows.

Characteristics associated with key types of unconfined PDCs are outlined in Figure 1, which highlights the wide range of impacts and deposits that can be produced; we provide more discussion and case studies below. Velocity and concentration thresholds are not easy to define but based on dynamics inferred or recorded in previous PDCs, we apply approximate thresholds of $5 \mathrm{~m} / \mathrm{s}$ and 1\% solid particle concentration by volume for the velocity and concentration, respectively, as indicative values for the boundary between "high" and "low" (Cole et al. 2015, Dufek et al. 2015) (Figure 1). 


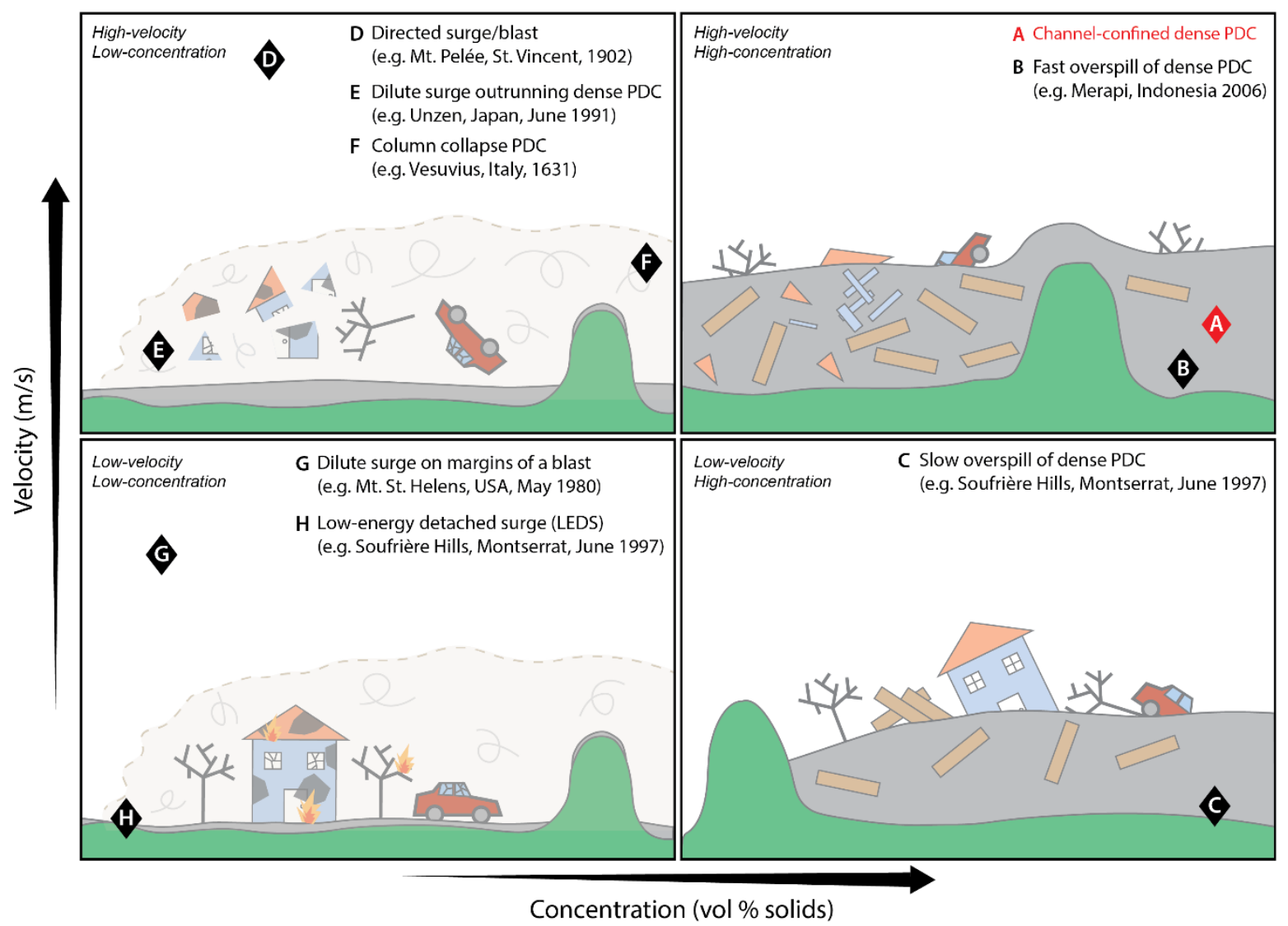

Figure 1: Unconfined Pyroclastic Density Current (PDC) matrix with schematics showing the interaction between PDC and topography, some impacts and an indication of the remaining deposit associated with the four end-member unconfined PDCs. Black diamonds indicate the relative velocity and concentration of the different types of unconfined PDCs, with one historical example shown for each type. The red diamond represents the characteristics of a high-energy channel-confined PDC for comparison. Note: Many of the eruptions provided as examples for each particular PDC type contained other PDC types as well.

\section{$2.1 \quad$ Fast overspill flows}

Fast overspill flows represent the high-velocity, high-concentration end-member of the unconfined PDC matrix. These flows are closely related to their parent channel-confined PDCs, and typically occur when the mass/volumetric flux of PDC in a channel surpasses the space available in the channel to contain it; for example through channel infilling from previous deposits. The result is the flow extending laterally beyond the banks of its confining channel and inundating areas adjacent to the channel. This can also occur at bends in a channel where the straight-line momentum of the PDC is sufficient to overtop the topographic margins of the channel. As a result, overspill flows are typically

201 close to the velocity of their parent channel-confined flows, which typically travel at speeds of up to $20230 \mathrm{~m} / \mathrm{s}$ and occasionally up to $60 \mathrm{~m} / \mathrm{s}$ (Cole et al. 2015). 
Overspill PDCs maintain both their high temperature and dynamic pressure, and thus cause damage through both heat and force. Parent channel-confined flows from hot lava dome collapse can be over $600{ }^{\circ} \mathrm{C}$, and fast overspills have been determined in several occurrences to have temperatures at or near their parent flows (e.g., Trolese et al. 2018, Wibowo et al. 2018), which can have dynamic pressures over $100 \mathrm{kPa}$ near source and over $15 \mathrm{kPa}$ in distal areas (Macorps et al. 2018). As with channel-confined PDCs, overspill flows typically destroy everything in their path, and cause the death and burial of people in inundated areas. For example, overspill flows during the 2006 eruption of Merapi caused two deaths through burial, and destroyed several buildings in the village of Kaliadem, $\sim 5 \mathrm{~km}$ from the volcano (Gertisser et al. 2012). Similar impacts are sustained by vegetation and infrastructure, with the high dynamic pressures damaging, bending, or completely knocking down trees and utility poles (e.g., Soufrière Hills June 1997, Loughlin et al. 2002; Merapi 1994; Abdurachman et al. 2000).

Since these overspill flows represent only the portion of the flow capable of extending beyond the channel, the deposits can be thin relative to the channel-confined PDC, but still geologically significant, on the order of 10s of centimetres to metres thick. Overspill deposits in the 2010 Merapi eruption were typically 1-2 m thick, and in isolated locations up to $5 \mathrm{~m}$ thick (Cronin et al., 2013), significantly thinner than the metres-thick channelized deposits, but thicker than the centimetres thick surge deposits (Charbonnier et al. 2013, Komorowski et al. 2013). Fast overspill flow deposits are typically poorly sorted and can contain up to metre-sized blocks in a medium or fine-grained ash matrix and are often not significantly visually distinct from confined flow deposits other than a generally lower presence of large clasts (Charbonnier and Gertisser 2008, Gertisser et al. 2012).

\subsection{Slow overspill flows}

Low-velocity, high-concentration PDCs are frequently represented by the peripheral edges or front of a slowing flow, but can also happen when a slow-moving dense flow escapes the bounds of its channel. As flows (channel-confined or not) reach areas more distal from the volcano or branches of the flow move farther from the primary flow axis, they reduce in energy (and therefore velocity) as a result of basal drag or friction acting on the dense layer while maintaining the same concentration (Shimizu et al. 2019). The result is a slow moving, but still highly-concentrated PDC. These dense slow-moving flows are easily stopped by topographic barriers (e.g., Soufrière Hills, Loughlin et al. $2002 a, b)$, which the less dense surge portions of the PDC are capable of decoupling from and surpassing. The fronts of slowing flows can have velocities that have dropped to 1-2 m/s (Cole et al. 2015). 
235 The high-concentration and typically high temperatures (similar to or slightly cooler than their 236 parent fast overspill flows, Trolese et al. 2018) of these flows means that they are still mostly fatal 237 for victims caught within their path; however, impacts on the built environment can be less binary.

238 The lower energy and dynamic pressures associated with a slower moving flow leads to inundation or damage of buildings and other infrastructure, with the peripheral parts of flows sometimes moving into or around impacted structures rather than sweeping them away (as described in Section 3.3). Nevertheless, a building that has been inundated with PDC deposits, but is largely undamaged, remains uninhabitable for its owner. Damage to trees and other vegetation is typically a function of the temperature and thickness of deposits, i.e. burial, rather than the violent total or partial blowdown or complete removal associated with higher dynamic pressures. As in fast overspill deposits, the concentrated nature of the flow results in a geologically significant poorly sorted deposit up to several metres (e.g., deposits from the 2006 eruption of Merapi were up to $8 \mathrm{~m}$ thick; Gertisser et al. 2012), although deposits become thinner (10s of centimetres or more) than the channel-confined parent flow the farther from the parent flow they are found (Charbonnier and Gertisser, 2008). The deposits are generally texturally and compositionally nearly identical to fast overspill deposits, and as a result the speed of an overspill flow is difficult to determine from deposit characteristics alone - in these cases, impacted infrastructure, as well as the extent of a singed zone from the overbank deposits, can be helpful for determining flow velocity (Charbonnier and Gertisser 2008).

\subsection{High-energy surge}

High-velocity, low-concentration PDCs are classified as high-energy surges, most commonly represented by directed blast eruptions, column collapse PDCs, and high-energy detached surges that decoupled from their parent PDCs. Directed blasts typically spread laterally from their source (most often the summit of a volcano) and are frequently generated by the explosion of a summit lava dome, shallow plug, or cryptodome, or through edifice collapse. These directed blasts are unconfined PDCs from point of origin, and tend to cover a very wide range, relatively unaffected by topography or channel confinement. Column collapse PDCs form from the gravitational collapse of a sustained ash column, and in many cases are characteristically similar to blast eruptions (e.g., Mt. Lamington, Papua New Guinea 1951; Belousov et al., 2020). By contrast, high-energy detached surges may originally be coupled with a fast-moving dense component and become unconfined by escaping the channel or otherwise changing direction from their parent flows, while maintaining their high velocities and dynamic pressures. Near source, velocities of directed blasts may be as high as 150 m/s (e.g., Mt. St. 
Helens 1980) and typically over $90 \mathrm{~m} / \mathrm{s}$ (Cole et al. 2015), while high energy detached surges maintain speeds up to those of their parent PDCs (up to $\sim 60 \mathrm{~m} / \mathrm{s}$; Yamamoto et al. 1993).

Directed blasts frequently have high dynamic pressure (over $10 \mathrm{kPa}$ ) close to source and along the primary flow axis, but lower dynamic pressures (less than $1 \mathrm{kPa}$ ) in more distal areas (e.g., Jenkins et al., 2013, Gueugneau et al. 2020) and in measured cases have shown temperatures over $300{ }^{\circ} \mathrm{C}$ (Cole et al. 2015). This results in a wide range of effects on humans, the built and natural environment, with fatalities and destruction from blunt trauma and thermal impacts in proximal zones, and with injuries and relatively little damage in the peripheral zones. In well documented cases such as the 1631 eruption of Vesuvius, column collapse PDCs displayed many directed blast characteristics, causing near total damage in the most affected areas through high dynamic-pressure and covering a widespread area (Rosi et al., 1993). Similar to blasts, the intensity of these PDCs wanes on the margins, where they can display non-binary impacts, with survival of people and structures indicating characteristics consistent with slow margins of dense PDCs as well as low-energy, dilute surges (Rosi et al., 1993). For example, the 1902 column collapse from La Soufrière, St Vincent, showed extensive damage in areas near source (Anderson and Flett 1903, Baxter 1990), but was not capable of overturning trees or sturdy structures by the time it reached heavily inhabited areas, $\sim 8$ $\mathrm{km}$ from source (Baxter 1990). Despite this, there were over 1500 deaths as well as nearly 200 hospitalizations (with 80 subsequent deaths) largely from burns and the asphyxiating effects of the ash (Will 1903, Baxter 1990). Similarly, in the 1902 Mount Pelée blast eruption (which had a death toll of ca. 29,000), people in St Pierre, $\sim 8 \mathrm{~km}$ from source, were severely burned by PDCs and fires with many laying prone in the "pugilistic attitude" frequently associated with deaths due to temperatures over $200^{\circ} \mathrm{C}$ (Anderson and Flett 1903, Will 1903, Lacroix 1904, Baxter 1990).

Detached pyroclastic surges that decouple from and/or outrun their parent flows can also maintain high dynamic pressure despite their low concentration. These surges are more capable of overcoming topographic barriers than their parent dense PDC, as was the case in the deadly June 1991 Unzen eruption, in which dilute surges detached from their parent flows and outran them by $0.8 \mathrm{~km}$, unexpectedly reaching an inhabited area where 43 people were killed (Nakada and Fujii 1993). The dynamic pressures of these surges were high enough (up to $8 \mathrm{kPa}$ in some parts of the surges; Clarke and Voight 2000) to destroy 50 houses, flatten trees, and move cars tens of metres (Nakada and Fujii 1993, Cooper 2018). Similarly, some high-energy detached surges in the 1994 Merapi eruption maintained dynamic pressures that remained high enough to topple masonry walls, 
down trees, strip roof tiles, and destroy bamboo huts $5 \mathrm{~km}$ from source (Abdurachman et al. 2000), which we estimate requires dynamic pressures of at least $2 \mathrm{kPa}$.

Deposits from these dilute, but high energy, surges are generally quite thin, but can reach greater thicknesses in depressions and valleys. Following the Unzen eruption, surge deposits were typically no more than $20 \mathrm{~cm}$ thick (Nakada and Fujii 1993) and were sometimes only a few centimetres thick, in contrast to the up to $10 \mathrm{~m}$ thick deposits from the parent flows (Miyahara et al. 1992). Deposits in the 1902 Mt. Pelée blast are estimated to range from $1.5 \mathrm{~m}$ along the main flow axis to $30 \mathrm{~cm}$ at the margins (Hovey 1904, Bourdier et al. 1989). Deposits from the 26 December 1997 blast at Soufrière Hills ranged from a few $\mathrm{cm}$ to $3 \mathrm{~m}$ outside of channels, while deposits were up to several metres thick in river valleys (Belousov et al. 2007). High energy blasts often leave a distinctive two-layer deposit (e.g., Soufrière Hills 1997, Merapi 2010) consisting of a basal, poorly-sorted, coarse layer that typically includes ripped up clasts of the underlying surface, overlain by a much finer-grained, better sorted deposit with some internal bedding (Brown and Andrews 2015; Komorowski et al., 2013).

\section{$2.4 \quad$ Low-energy detached surge (LEDS)}

LEDS represent the low-velocity, low-concentration end of the unconfined PDC spectrum. These slow-moving surges $(\sim 1-2 \mathrm{~m} / \mathrm{s})$ represent the upper dilute layer of a PDC that has detached from its dense, basal flow layer (Lube et al 2011, Cole et al. 2015, Dufek et al. 2015). The buoyant nature of these surges allows them to easily overcome topographic barriers. In recorded events, these surges are most commonly seen moving laterally from their confined parent flows and escaping channels, leading to unexpected inundation of inhabited areas. How, why or where along the flow path a surge detaches is typically related to a change in the underlying syn-eruptive topography and/or the pulsative nature of the eruption, which can act to reduce channel capacity or redirect the channel away from the straight-line flow inertia, as described in the Introduction.

Due to their low velocity and concentration, and thus low dynamic pressure (typically <2 kPa), LEDS damage to buildings, infrastructure or vegetation is typically minor (with the exception of secondary damage through fire). For example, in the June 1997 Soufrière Hills eruption, LEDS were not capable of blowing down trees or poles at distances greater than $2 \mathrm{~km}$ from source (Cole et al. 2002) and damage to buildings was caused almost exclusively by temperatures up to around $400{ }^{\circ} \mathrm{C}$ (Baxter et al. 2005). The impact for humans can range from minor through to fatal burns injuries, with the chances of survival influenced by the LEDS temperature and duration as well as how much skin is exposed by clothing, to what extent the victims breathe in the LEDS, and the availability and timing 
of medical resources (Baxter, 1990). The bodies of victims in such PDCs often show evidence of brief exposure to extreme heat, with many of the limbs flexed into the "pugilistic attitude" associated with fire and PDC deaths (e.g., Soufrière Hills, June 1997, Merapi 1994: Baxter, 1990; Baxter and Horwell, 2015; Baxter et al., 2017).

Temperatures in these types of surges have been observed to be at least $180{ }^{\circ} \mathrm{C}$ and up to over 410 ${ }^{\circ} \mathrm{C}$ based on both direct measurements (Soufrière Hills 1997; Loughlin et al. 2002a) and proxy estimates based on damage to vegetation and buildings (Merapi; Voight and Davis 2000, Unzen; Fujii and Nakada 1999). In some events a "sear zone" or "singe zone" of charred vegetation was seen to extend up to $25 \mathrm{~m}$ beyond the distal margins of surge deposits (Loughlin et al. 2002a).

The deposits of LEDS are characterized by their relative thinness and poor preservation in the longterm geologic record. In most historical cases, these surges have been recorded as thin as a few centimetres and no thicker than $20 \mathrm{~cm}$, even when associated with metres-thick, channel-confined PDCs (e.g., Soufrière Hills 1997; Cole et al. 2002, Druitt et al. 2002; Merapi 1994; Abdurachman et al. 2000; Unzen 1991: Miyahara et al.1992). Deposits tend to mantle the landscape as a result of settling from the dilute surge (Druitt et al. 2002) and are typically thinnest in open areas (Abdurachman et al. 2000). Most observed deposits are massive and normally graded, generally lacking any internal stratification, but deposits may contain multiple discrete layers if the event involved more than one surge pulse (Abdurachman et al. 2000, Cole et al. 2002, Druitt et al. 2002). In most cases, the deposits are poorly sorted ash but may contain lapilli and rare blocks in addition to gas segregation pipes and mixed in soil and charred wood fragments picked up in transit (Abdurachman et al. 2000, Druitt et al. 2002).

Single eruptive events may contain both high- and low-energy detached surges, as seen in the 1991 Unzen eruption. In the June event, deadly high-energy surges killed 43 people and had dynamic pressures large enough to sweep away cars and trees in one area (Cooper 2018), while low-energy surges were capable of burning, but not bending or breaking, trees in other areas (Nakada and Fujii 1993). Similarly, in the September Unzen event, high-energy surges in some locations were powerful enough to sweep away cars and trees damaged in the earlier eruption, while in another location lowenergy surges caused damage only though heat, melting vinyl and charring building windows on the volcano-facing side of the buildings (Fujii and Nakada 1999). Dynamic pressures in these events may be up to $8 \mathrm{kPa}$ in the high-energy surges, and lower than $2 \mathrm{kPa}$ in the low-energy surges (Clark and Voight 2000). 


\section{The 2010 Merapi eruption}

361 The full spectrum of confined and unconfined PDCs can occur within one eruption, affecting multiple 362 places at the same time, or the same place at multiple different times. PDCs produced during the 2010

363

364

365

366

367

368

369

370

371

372

373

374

375

376

377

378

379

380

381

382

383

384

385

386

387

388

389

390 eruption of Merapi in Indonesia provided one such example. Post-eruption field studies of the PDC impacted areas offered a unique opportunity to characterise the range of PDC types, their dynamics, deposits and interaction with populated areas to the south of the volcano. Here, we synthesise the sequence of PDC events and their impacts and present new data for key villages along the Gendol river. We focus on slow overspill flows and low-energy detached surges, as these two unconfined PDC end-members and their impacts are poorly documented in the literature.

After approximately one year of unrest, Merapi volcano began a new eruptive sequence on 26 October 2010 with the explosion of a cryptodome and associated high-energy PDCs laterally directed towards the south. These initial PDCs extended $6.8 \mathrm{~km}$ from the summit and killed 35 people who had not evacuated (Jenkins et al., 2013, 2016). Unusually rapid dome growth (to $25 \mathrm{~m}^{3} / \mathrm{s}$ ), with recurrent explosions and PDCs continued from 29 October until the paroxysm on 5 November (Surono et al. 2012, Pallister et al. 2013, Komorowski et al., 2013, Charbonnier et al., 2013). On 5 November, starting at 00:02 local time (UTC +7), a series of five laterally directed dome explosions occurred, concurrent with retrogressive collapse of the dome, resulting in at least four distinct types of PDC in under 15 minutes: high-energy unconfined PDCs, dense valley-confined flows, overspill flows, and detached surges (Komorowski et al. 2013). Further gravitational dome collapse, fountain and sub-Plinian column collapse led to PDCs that extended to $15.5 \mathrm{~km}$ in the Gendol valley in the south, with flow overspills and low-energy detached surges extending $700 \mathrm{~m}$ from the channel and up to $200 \mathrm{~m}$ from the parent flow (Charbonnier et al. 2013, Komorowski et al. 2013, Jenkins, et al., 2016). PDC overspill and detachment along the more distal parts of the Gendol channel ( $>8 \mathrm{~km}$ from source) during this paroxysmal phase killed $\sim 170$ people (Jenkins et al., 2013, 2016) and damaged $(n=395)$, severely damaged (removed the roof: $n=108)$ or destroyed $(n=645) 1,148$ buildings. This event was termed a 'centennial' eruption (Surono et al., 2012), as this magnitude and style of eruption is seen approximately every 100 years at Merapi.

Field visits to the Merapi area three weeks after the 5 November 2010 event, and several times over the years that followed, allowed some of the authors [SFJ, SJC, JCK, and PJB] to collect detailed field data on confined and unconfined PDCs produced during the eruption. The geology, dynamics and impacts associated with the directed blast that affected a large swathe of the upper flanks to $\sim 8 \mathrm{~km}$ 
391 from the summit are presented in Komorowski et al. (2013) and Jenkins et al. (2013). Here, we focus

392 on the generation mechanisms, deposits, impacts and inferred dynamics associated with i) slow

393 overspill flows, and ii) low energy detached surges in villages along the Gendol river channel more

394 than $10 \mathrm{~km}$ to the south of the summit. Fast overspill flows were also observed along the Gendol, but

395 impacts were total, with all buildings, vegetations and victims buried with no observable remains.

396 Uniquely, our field studies combined geological and engineering expertise in collecting and

397 interpreting data on the deposits and physical impacts of the unconfined PDCs, which could be cross-

398 referenced with medical data on the nature of burns injuries to victims. Some of the geology

399 (Charbonnier et al., 2013, Cronin et al. 2013) and impacts (Jenkins et al., 2013; 2016; Baxter et al.,

400 2017) from these more distal unconfined PDCs during the Merapi 2010 eruption have been discussed

401 previously; here we present data not included in these studies. We hope that these data and

402 interpretations are valuable for emergency management planning in providing the first multi-

403 disciplinary case study of unconfined PDCs and their impacts.

\section{$404 \quad 3.1 \quad$ Case study sites}

405 We focus on two distinct type of unconfined PDC, for which we discuss the associated generation 406 mechanisms, dynamics, impacts and deposits at two villages (Figure 2):

- Bakalan, $12.6 \mathrm{~km}$ straight-line distance from the summit and on the western edge of the Gendol river channel. The distal slow-moving portion of a fast overspill flow on 5 November inundated 31 buildings within this village, with associated LEDS impacting a further 9; we concentrate on the impacts within the area inundated by the dense flow for this case study. Residents had evacuated the village prior to flow inundation.

412 - Bronggang village, $\sim 13.5 \mathrm{~km}$ from the summit, on the western edge of the Gendol river channel, 413 and bordering a sabo dam bridge that crosses the channel. During the 5 November paroxysmal 414 phase of the eruption, LEDS impacted 48 buildings in Bronggang, killing 54 people who were in the process of evacuating. 


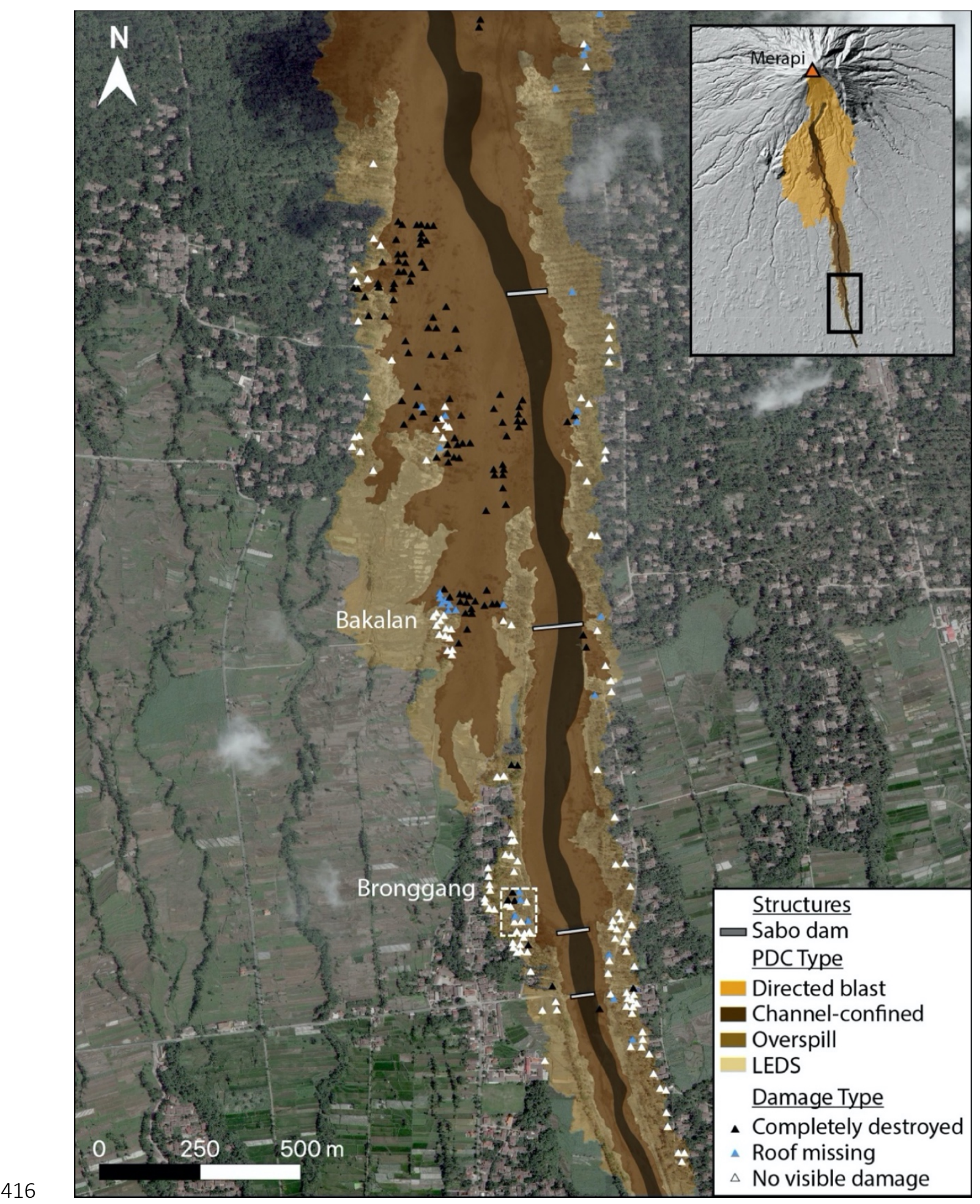

417 Figure 2: Channel-confined, overspill and detached PDCs along the Gendol river valley following the 5 418 November 2010 eruption of Merapi. Coloured triangles indicate level of damage observed in buildings 419 in pre-and post-eruption satellite images (Jenkins et al., 2013). Digital Globe optical Basemap imagery 420 (image acquired 11 Nov, 2010). White box surrounding buildings in Bronggang shows the locations of 421 buildings presented in Figure 5. Inset shows the village locations relative to the summit and wider PDC 422 impacted area. 


\subsection{Slow overspill flow: Bakalan village}

424

425

\subsubsection{Generation}

The flow first overspilled the main Gendol channel nearly $2 \mathrm{~km}$ upstream to the north, likely because of a bend in the channel towards the east and previous infilling of the channel with PDC deposits emplaced on 4 and 5 November (Charbonnier et al., 2013). Significant narrowing of the channel, and thus a reduction in channel capacity, approximately $1 \mathrm{~km}$ to the north upstream of Bakalan village, along with a number of sabo constrictions along the channel, may also have played a role in creating further overspill flows that inundated the village (Figure 2). Bakalan marks the distal margin of the overspilling flow, with 9 of the 40 buildings in the village affected by LEDS, and 31 by the overspilling flow (Figure 2).

\subsubsection{Impacts}

Slow overspill flows up to $2 \mathrm{~m}$ thick inundated 6 buildings without destroying, burying or sweeping them away (Figure 3a-c); a further 8 sustained major damage to the roof and some walls but remained partially standing (Figure 3d). Less resistant timber outhouses and animal shelters were destroyed by any inundation of dense flow. The gradation of building damage from complete destruction through to buildings remaining standing, despite flow having inundated the building envelope, was gradual but extended over a relatively short distance of $\sim 50 \mathrm{~m}$. Within this zone of rapid damage attenuation, building conditions fell mostly into one of two categories (with increasing distance from the parent flow):

1. Inundation with little to no structural damage, although roof tiles, rafters and purlins were lifted from the overhanging portion of the roof facing the flow. Roof tiles were cracked and/or penetrated by larger clasts carried within the dilute component of the PDC (Figure 3a and b).

2. Dense flow blocked by the walls of buildings, with little to no inundation through openings such as cracked glazing or doors; roof tiles remained unaffected (Figure 3c).

In addition to these main scenarios, we observed more severe damage where: i) isolated fires had ignited building contents and burned roof supports causing roof failure in one or more rooms, and ii) boulders of up to $1 \mathrm{~m}$ diameter carried within the flow caused structural failure of one or more walls (Figure 3d). Buildings in Bakalan village that were outside of the dense flow overspill and affected only by LEDS sustained similar impacts to those in the Bronggang area (Section 3.3). It is possible that fires observed in the area inundated by the dense flow were ignited by the passing of LEDS that 
preceded the dense overspill, particularly as fire damage is observed in those buildings in Bakalan that were impacted only by the LEDS. However, any damage caused by the LEDS is expected to be of lesser consequence than that caused by the dense overspill; the brief gap in time between the two PDCs means that the temperature of the LEDS and flows were likely not markedly different, i.e. fires apparently caused by LEDS could also have been caused by the flow.

People were evacuated from Bakalan prior to the 5 November event, although locals reported between four and five fatalities in the village.

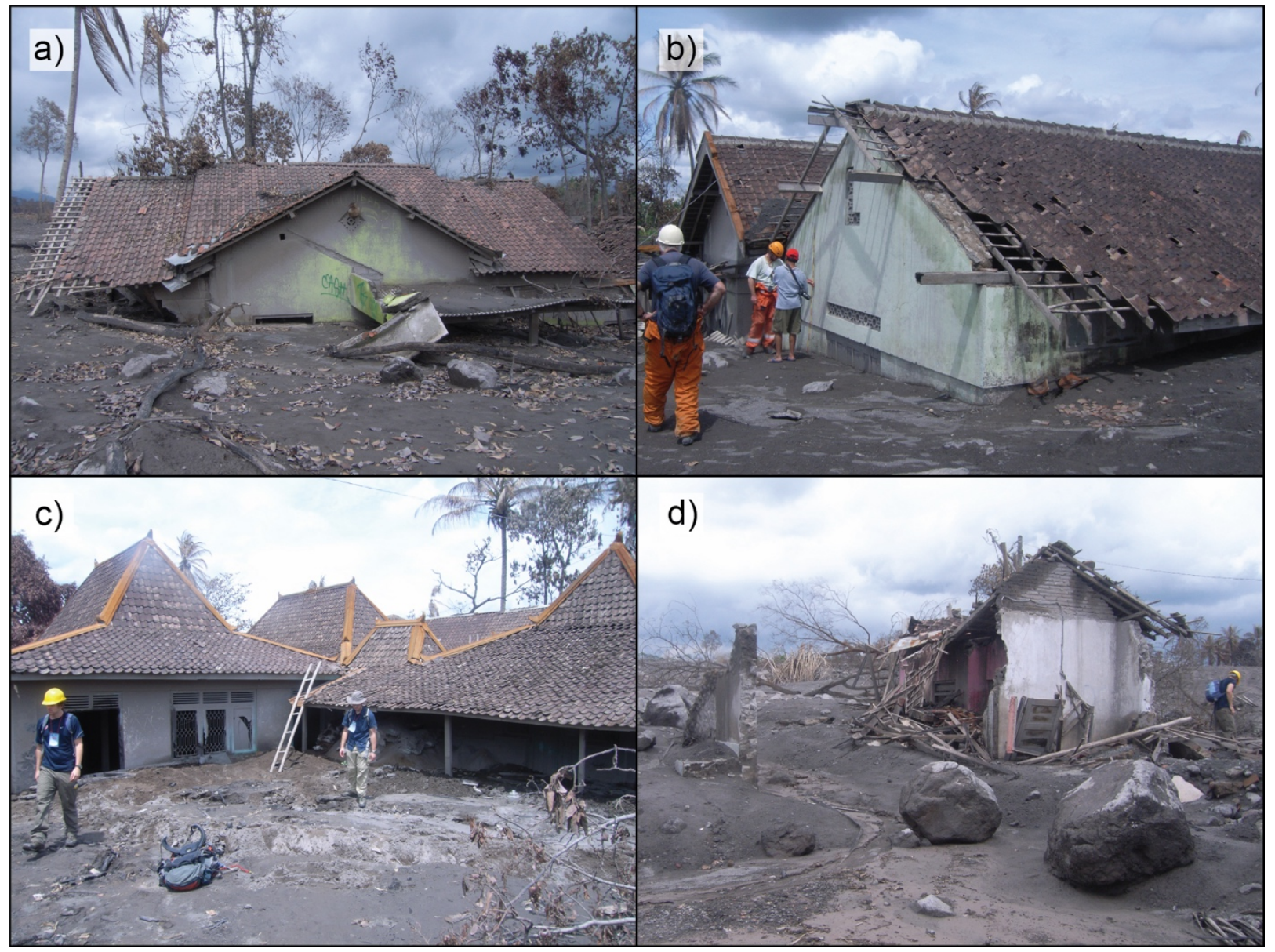

Figure 3: Photos of slow overspill flow impacts in Bakalan village including: a) Thick deposits of up to $2.5 \mathrm{~m}$ partially burying houses and causing structural damage on upflow side of structure, $b$ ) inundation with minor structural damage, c) flows blocked by building fronts, resulting in little to no inundation, d) severe structural damage caused by large boulders carried by the dense flow. Photos taken 7 December 2010 by S.F. Jenkins.

\subsubsection{Deposits}

Stratigraphic sections studied after one rainy season in the Bakalan village show a massive, poorlysorted overspill flow unit with blocks inside an ash-rich matrix, of $\sim 2-3 \mathrm{~m}$ thickness overlying three 
1-8 $\mathrm{cm}$ thick LEDS units at the base. Overbank deposit thicknesses in the Bakalan area vary from 2 to $7 \mathrm{~m}$ and two overbank units are present in stratigraphic sections located at the overspill point, $\sim 1 \mathrm{~km}$ upstream of the village (Figure 2). Based on stratigraphic data from the valley-confined PDC deposits collected in the Gendol channel in summer 2011, only two valley-confined PDC units reached that far downstream during the 5 November events (mBLA4 and mBLA5 units in Charbonnier et al., 2013). Based on stratigraphic correlations between the valley-confined and unconfined deposits, only the uppermost valley-confined unit (mBLA5) produced the main overspill flow unit that reached Bakalan, while the lowermost one produced the surge layers found at the base of the unconfined deposit stratigraphy.

\subsubsection{Dynamics}

The height of the unconfined PDC as it was emplaced remained above $10 \mathrm{~m}$ throughout Bakalan, as evidenced by palms and trees that were singed to their full height (e.g., Figure 3a). Just to the west of the village and on the periphery of the LEDS, partially singed trees suggest current heights for the more dilute component alone of between 5 and $10 \mathrm{~m}$. Much of the structural damage to buildings in the north of Bakalan was the result of isolated high pressures associated with boulders of dome rock carried within the flow (e.g., Figure 3d). The lack of structural wall failure within the main part of the slow overspill flow suggests dynamic pressures of less than $3 \mathrm{kPa}$ (following the failure calculations of Jenkins et al., 2013). Maximum PDC velocities, assuming a dense PDC density of $1000 \mathrm{~kg} / \mathrm{m}^{3}$ (Druitt et al. 2002, Dufek et al. 2015), were relatively slow at $2.5 \mathrm{~m} / \mathrm{s}$ (Equation 1):

$V=\sqrt{\frac{2 q}{\rho}}($ Equation 1$)$

Where $V=$ velocity $(\mathrm{m} / \mathrm{s}), q=$ dynamic pressure $(\mathrm{Pa}), \rho=$ density $\left(\mathrm{kg} / \mathrm{m}^{3}\right)$. The overspill flow that entered Bakalan from the north appears to have been relatively low in temperature, at 100 to $200{ }^{\circ} \mathrm{C}$. A number of thermal indicators could be used to infer emplacement temperatures of the LEDS (see Section 3.3.4) while for the dense flows, temperatures were constrained from the presence of little to no charring or blackening of timber roof supports $\left(<200{ }^{\circ} \mathrm{C}\right.$ : Barcík et al., 2014) and the presence of deformed polyethylene plastic pipes within the upper part of the flow deposits $\left(>100{ }^{\circ} \mathrm{C}\right)$. PDC deposits to the south of Bakalan, but closer to the Gendol channel, remained at $180{ }^{\circ} \mathrm{C}$ during field studies carried out 34 days after emplacement, supporting the relatively low flow temperatures estimated within Bakalan. These temperatures are low relative to some dense unconfined deposits from other eruptions, with deposits from the June 1997 Soufrière Hills eruptions measured in the 
days to weeks after the event at over $400{ }^{\circ} \mathrm{C}$ (Cole et al. 2002), though unconfined deposits from the 2015 dome collapse events at Colima (Mexico) show temperatures from 180 to $220{ }^{\circ} \mathrm{C}$ (Pensa et al. 2018). Lower temperatures at Merapi in 2010 may reflect entrainment of air over the long travel distance and interaction of PDCs with dense, tropical vegetation, while other factors could include the relatively small magma volume, the effect of topography in entraining cooler, ambient air close to source, and/or the high moisture content of the PDCs due to the summit hydrothermal system saturating the source dome rock (Jenkins et al., 2013; Komorowski et al., 2013).

\subsection{Low-energy detached surge: Bronggang}

\subsubsection{Generation}

The channel constriction caused by the sabo dam and upstream concrete levees, in addition to a slight bend in the river channel towards the east at the northern edge of Bronggang village (Figure 2), are thought to have promoted surge detachment from the parent channel-confined flow (Jenkins et al. 2013). LEDS then propagated around 6 to $8 \mathrm{~m}$ down the concrete levees and extended laterally 25 to $135 \mathrm{~m}$ into Bronggang via three different entry points. Numerous deeply charred logs and embers were left piled up on the top of the concrete sabo walls that run alongside the Gendol channel, marking where the surges detached (Figure 4). A few small logs were carried down into the villages, potentially bending or knocking down banana trees as they collided into them down the incline. A more concentrated PDC lobe overspilled for a very short distance of about $20 \mathrm{~m}$ directly over the highest part of the sabo wall but at the location of maximum channel curvature, where the levees constrict at a $45^{\circ}$ angle towards the centre of the Gendol river channel. Although the presence of this wall and constriction in the channel strongly controlled and even triggered early PDC overspill into the lower part of Bronggang, our fieldwork showed that only three out of four or potentially five surges associated with valley-confined PDCs overspilled at that location. 


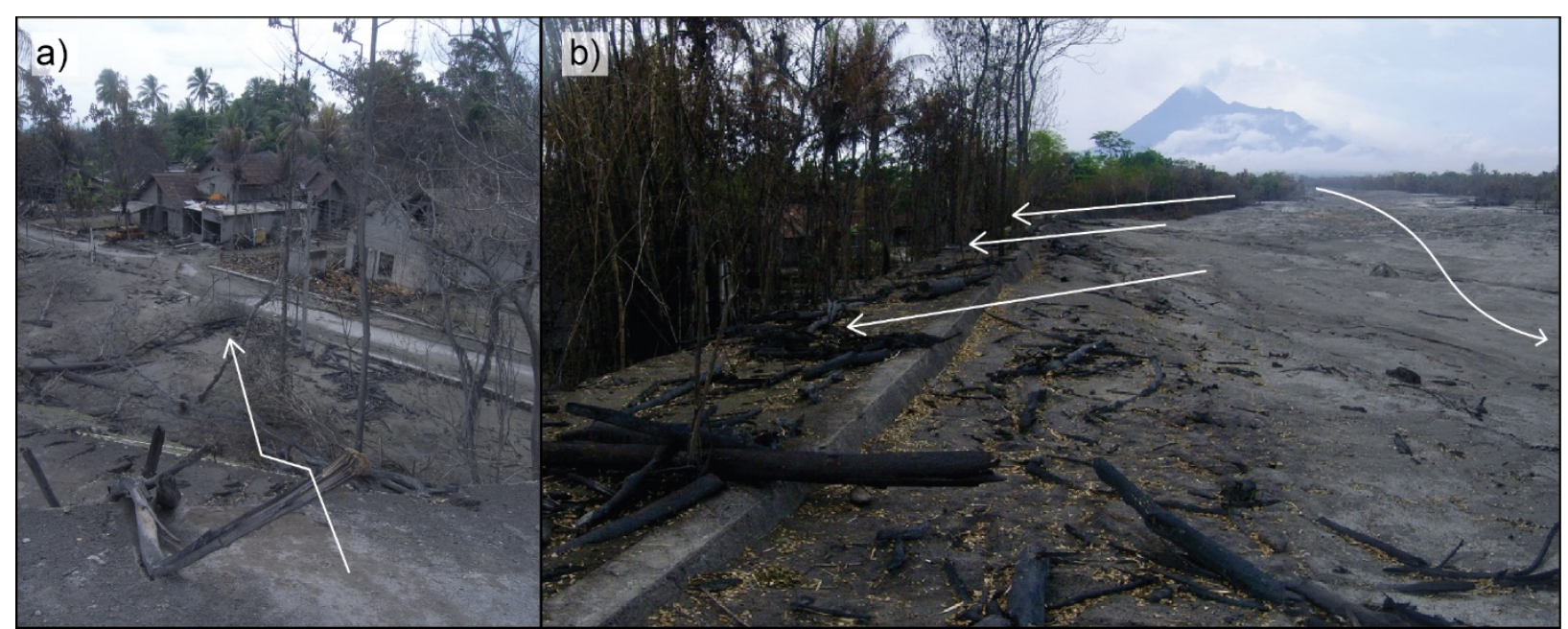

Figure 4: Photos taken from the top of the concrete levee bordering the Gendol and adjacent to Bronggang village: a) Looking southwest down the levee and in the direction of LEDS spillover into Bronggang village; b) Looking north up the infilled Gendol channel with LEDS and small flow overspill into Bronggang to the left of the image. Charred tree branches and embers that were carried within the PDC can be seen on top of and within deposits in the channel and in the village. Photos taken by S.F. Jenkins 25 days after impact on 30 November 2010.

\subsubsection{Impacts}

Direct damage from the LEDS was minimal, with buildings remaining largely intact but interior and exterior plastic melted, furniture charred and paper singed. Although the LEDS were not hot enough to directly ignite these flammable objects, fire was the cause of total and partial destruction of buildings in the village. Of the 48 buildings impacted by LEDS in Bronggang, seven timber buildings were completely destroyed and a further five masonry buildings, with timber frame and tiled roofs, partially destroyed, all by fire rather than direct damage from the LEDS (Figure 5a). Firebrands (embers from burning logs within the parent PDC) carried within the surge ignited flammable materials such as hay in animal sheds and sticks and coconut husks in outside lean-to wooden kitchens (Figure 5b), with fires beginning in these flimsy wooden structures and then rapidly spreading into the adjacent houses. The large ventilation gaps also allowed firebrands to travel with the ash inside several houses, as evidenced by ignited mattresses or sofas, which smouldered without causing the houses to catch fire (Figure 5c). In one building, a small rupture in the gas tank of a motorbike stored inside greatly increased the availability of fuel leading to a fire that completely destroyed the building.

Prior to the eruption, $\sim 400,000$ people were rapidly evacuated to emergency shelters (Surono et al. 2012) and $\sim 1$ million were otherwise displaced (Lavigne et al. 2011), but in distal villages like Bronggang many people had not evacuated at the time of the paroxysm. Out of 59 people remaining 
547 in the surge zone, all of whom received burns, there were only 5 survivors. Those who were caught 548 outside had little protection and most would have died instantly (Baxter et al., 2017); however, large 549 ventilation pathways meant that the LEDS readily entered buildings and twenty-five bodies were 550 retrieved by rescuers from inside houses. A further 18 bodies were found outside, and 11 others died 551 in, or on the way to, hospital (Figure 5a, Jenkins et al., 2013, Baxter et al., 2017). Some of the victims 552 received burns from running in the deposits as they tried to escape and a cow was found alive at the 553 time of the first rescue mission, approximately two hours after impact, but subsequently died. The 554 last living person was rescued by approximately 06:00 (local time). Specifics of the injuries suffered 555 by the burn victims are described in medical detail by Baxter et al. (2017). Survival of hospitalized 556 patients was tied closely to quality of medical care, as resources in some cases were insufficient (e.g., 557 ventilators for treating inhalation injuries) (Baxter et al. 2017). 


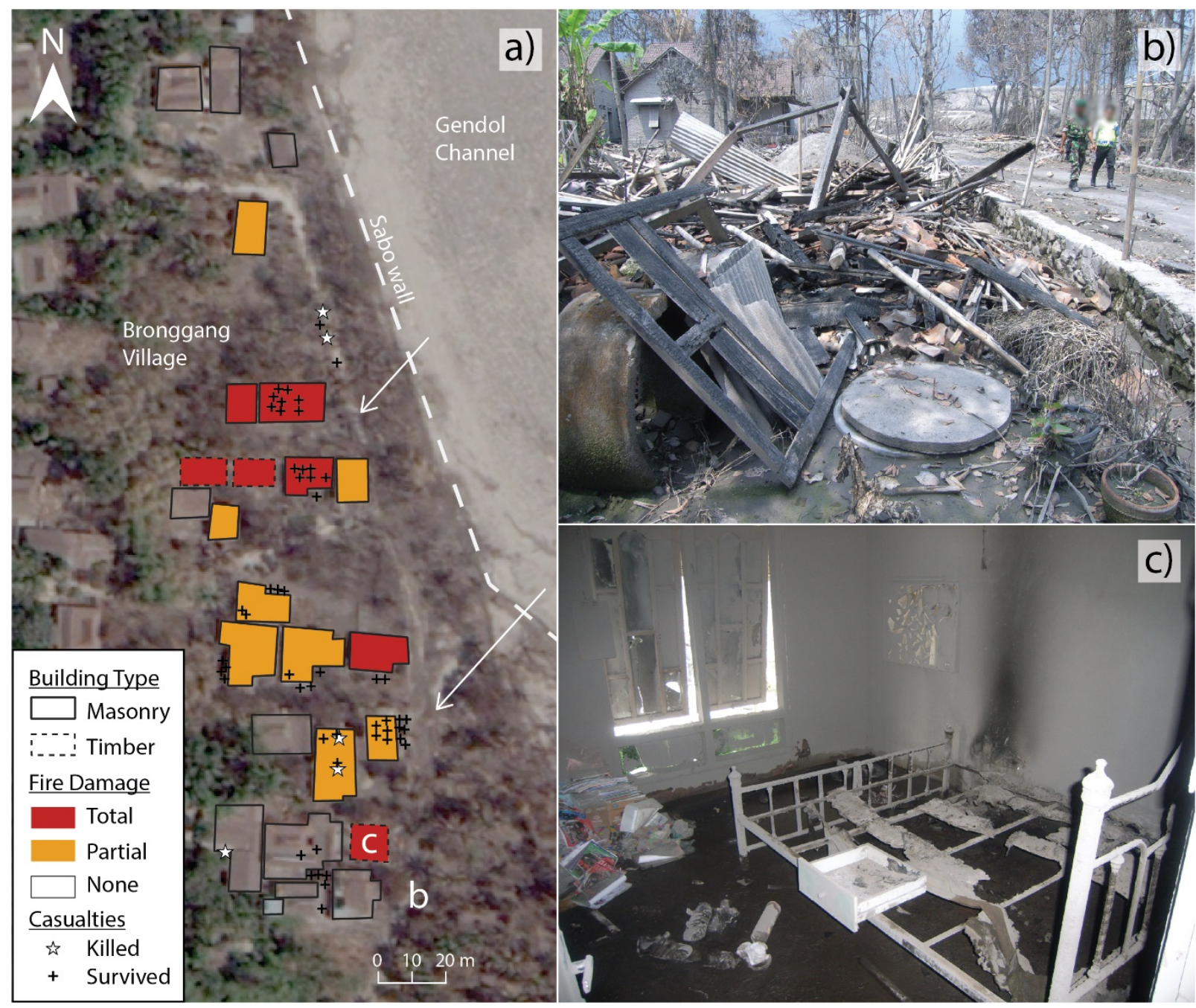

Figure 5: a) Spatial distribution of building type, fire damage and casualties in a section of Bronggang village (inset in Fig 2), 13.5 km from the summit and subject to LEDS. LEDS flow direction across sabo walls is indicated by white arrows with the white dashed line marking the sabo concrete levees bordering the Gendol channel, b) remains of a burned and charred timber-framed building that was totally destroyed by fires caused by LEDS (Photo taken by S.F. Jenkins 28 days after impact on 3 December 2010), c) straw mattress burned by an isolated fire as a result of LEDS inundation (Photo

567 taken by S.F. Jenkins 29 days after impact on 4 December 2010). The location of the images in (b) and 568 (c) are marked by the corresponding letters in (a).

\subsubsection{Deposits}

570 We identified a complex stratigraphy at the base of the sabo wall, just inside the village of Bronggang,

571 consisting of four different main depositional units (Figure 6):

- At the base of the sequence, there were patches of dry very fine grained, very well-sorted, loose 
- The next unit was whitish-grey massive, coarse to fine ash, loose, poorly sorted and 3-4 cm thick with chunks of charcoal and a burnt odour. We interpreted this unit as a LEDS deposit contemporaneous or correlated to one of the surge units seen in the main Gendol channel. This unit contained pieces of aluminium foil, house tiles, and dried to scorched leaves. It was overlain by a $2 \mathrm{~cm}$ thick very fine-grained pinkish-tan ashfall layer.

- The third unit was a dark grey, fine ash, massive, well-sorted and normally graded $4 \mathrm{~cm}$ thick unit with chunks of charcoal and a locally erosive lower contact. We interpreted this unit as a second LEDS deposit contemporaneous or correlated to one of the surge units seen in the main Gendol channel. It was again overlain by a $1 \mathrm{~cm}$ thick, very fine grained, pinkish-tan, ashfall layer.

- The uppermost unit was a very poorly sorted, massive, compact, pinkish brown, normally to symmetrically and even reversely graded, $35-45 \mathrm{~cm}$ thick fines-rich unit. This unit contained large dense clasts up to $23 \mathrm{~cm}$ in diameter scattered on the top surface and also formed a central coarser clast-rich zone with a more pinkish matrix. We interpreted this unit as resulting from a minor overspill lobe of a valley-confined, block-rich PDC. Field evidence suggests that this PDC was not very mobile and was stopped by the $\sim 30 \mathrm{~cm}$ tall stone-wall curb of the main village road on the Gendol side (Figure 6). This unit was correlative and thickened to a $93 \mathrm{~cm}$ thick sequence directly on top of the sabo wall. It was overlain by a 5-6 cm thick, very well-sorted, massive, fine pinkish tan ashfall layer with a vesicular texture and perhaps some poorly preserved accretionary lapilli.

We interpreted these deposits as representing three different minor PDC overspills, and associated ash cloud fallout, from the Gendol main channel: the lower two represent deposition from the dilute surge component only, while the upper unit includes deposition from the dense flow component as well, although this did not propagate as far as where the buildings are in the village. Parent PDCs remained largely channelized in the Gendol. LEDS depositional units were visible outside of the buildings, although only the very fine ash component of LEDS infiltrated inside (Figure 6). No stratification in deposits could be seen inside the buildings, suggesting that only one of the LEDS infiltrated, or the material was lofted and well dispersed so that it settled out gradually into one massive unit of up to $2 \mathrm{~cm}$ thickness that coated items inside the building (Figure 6). 


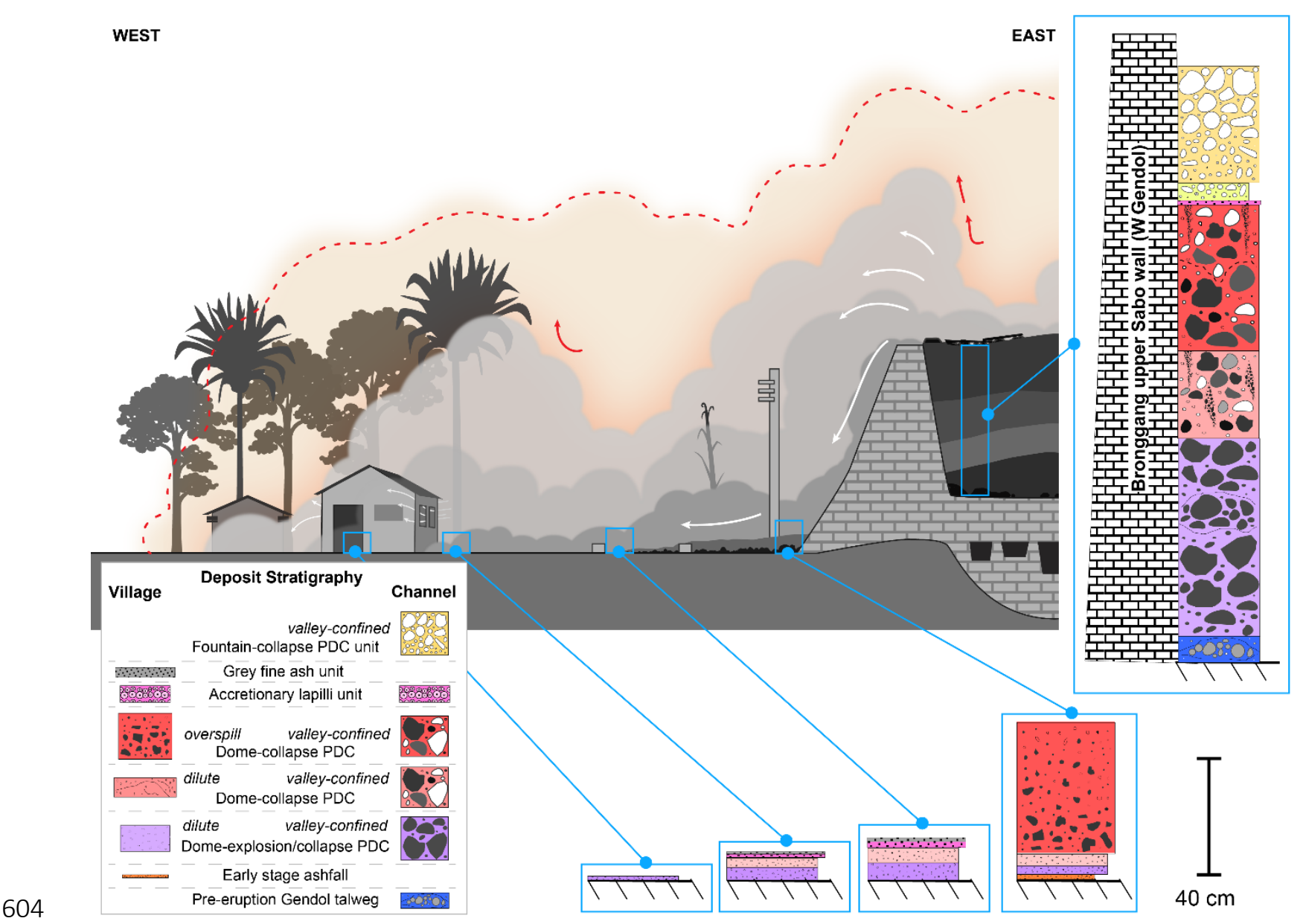

605

606

607

608

609

Fig 6: Schematic demonstrating the dynamics of LEDS as it leaves the channel and inundates Bronggang with stratigraphy of channel-confined, overspill and LEDS deposits in and adjacent to Bronggang, 13.5 $\mathrm{km}$ from the volcano summit.

\subsubsection{Dynamics}

Evidence from the height of scorching on trees in the village indicated that the dilute current was at most about 8-10 $\mathrm{m}$ high above the village (2 to $4 \mathrm{~m}$ above the levee tops). In Bronggang, at the base of the concrete levee bordering the Gendol channel, a concrete utility pole of $\sim 7.5 \mathrm{~m}$ high showed pockmarks, from small clasts within the LEDS striking the pole, of $\sim 10-20 \mathrm{~mm}$ diameter and a few $\mathrm{mm}$ deep along the full height of the pole on the upflow side (Figure 7a). The boundary between the area of scorched, dried vegetation and pristine vegetation was very sharp, developing over less than $1 \mathrm{~m}$. Figure $7 \mathrm{~b}$ shows a traditional Javanese building at the very periphery of the LEDS affected area in Bronggang, where ash adhered to the wall of the building facing the flow, and nearby vegetation dried and singed to a height of approximately $5 \mathrm{~m}$, with some tiles dislodged on the roof overhang. Vegetation and building components to the side and back of the building (farther from the flow) were unaffected. Thus, at the edge of the surge, as evidenced by the vegetation patterns (Figure $7 \mathrm{~b}$ ), the 
LEDS height was still about $5 \mathrm{~m}$. Taking the maximum LEDS height of 8-10 $\mathrm{m}$ and maximum deposit thicknesses of $\sim 4 \mathrm{~cm}$ (Section 3.3.3) gives a crude estimated maximum LEDS density of $\sim 4$ to $5 \mathrm{~kg} / \mathrm{m}^{3}$ (conservatively assuming a $1000 \mathrm{~kg} / \mathrm{m}^{3}$ deposit density as for Soufrière Hills: Druitt et al., 2002). Previous estimates of LEDS densities are rare, but for comparison, Druitt et al. (2002) estimated that in the June 1997 Soufrière Hills eruption, LEDS moving at up to $20 \mathrm{~m} / \mathrm{s}$ likely had a density of 1.4 $\mathrm{kg} / \mathrm{m}^{3}$ and a particle concentration below $0.1 \mathrm{vol} \%$, and Bursik et al. (1998) estimated distal surges in the $1980 \mathrm{Mt}$. St. Helens eruption to have a density of $1.5 \mathrm{~kg} / \mathrm{m}^{3}$.
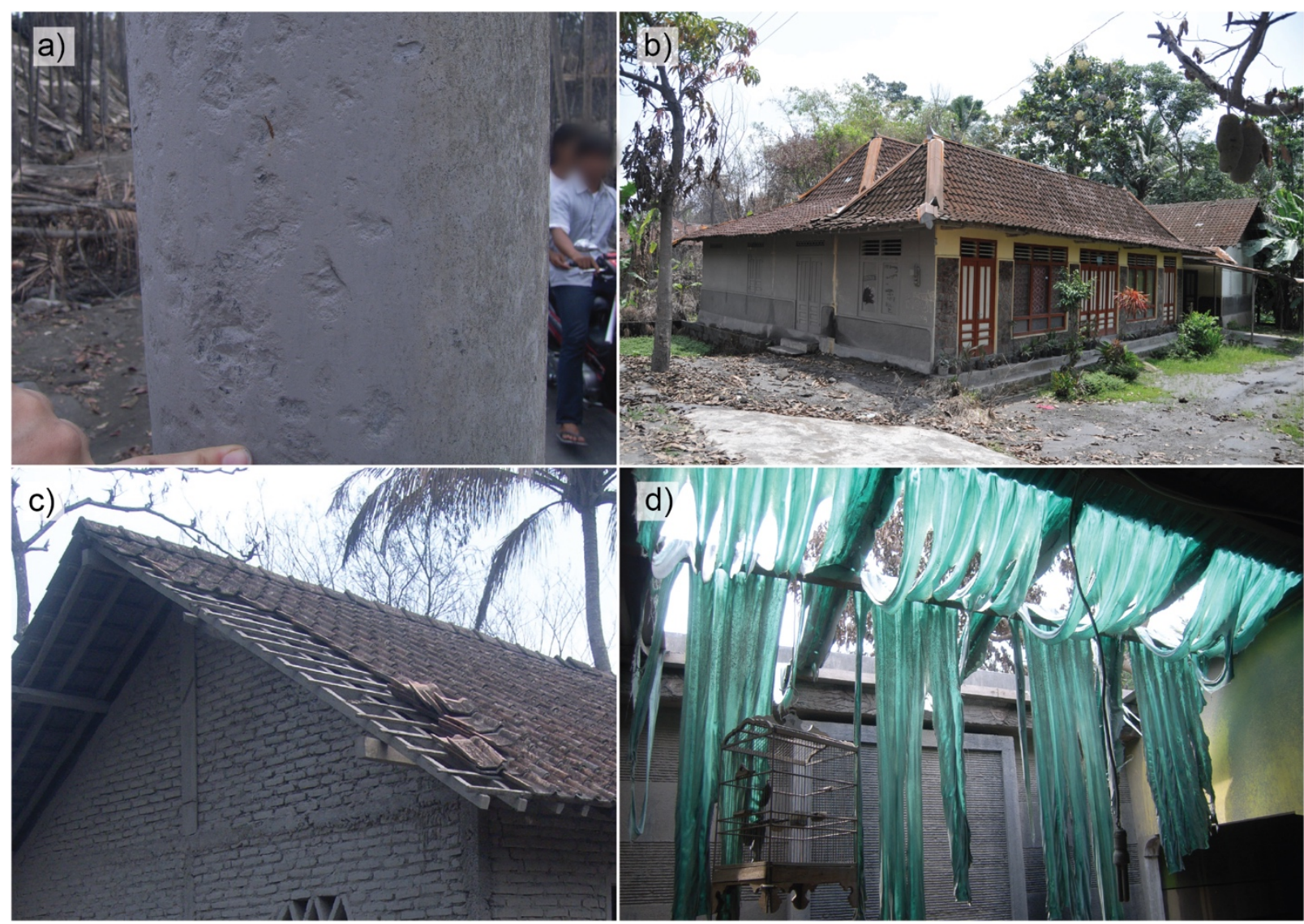

Figure 7: a) 7.5 m high concrete utility pole at the base of the concrete levee bordering the Gendol channel showing pockmarks on the upflow side, from small clasts carried within the LEDS striking the pole; b) Traditional Javanese building at the edge of Bronggang village showing the very sharp LEDS boundary, with ash and dried vegetation from the LEDS visible on just the upflow (left of image) wall and surrounds; c) Roof tiles lifted on the overhang of a building facing the direction of LEDS overspill suggesting dynamic pressures of $\sim 0.1$ to $0.2 \mathrm{kPa}$; d) Corrugated plastic roofing sheets melted by the LEDS and/or the deposits suggesting temperatures of at least $100{ }^{\circ} \mathrm{C}$ sustained for $\sim$ three minutes. Photos taken by S.F. Jenkins, November 2010.

Maximum velocities of $10 \mathrm{~m} / \mathrm{s}$ for the LEDS as they spilled over the concrete levee can be derived by applying the super-elevation equation (Equation 2) to the estimated $5 \mathrm{~m}$ high concrete levee that would need to have been overbanked by the LEDS associated with the first overspilling PDC in the 
Gendol. This represents the maximum possible velocity of the LEDS at their point of overspill from the channel-in reality, the LEDS would likely have had lower velocities as they entered the village. Subsequent LEDS would have required lower velocities in order to overspill after previous PDCs infilled the channel, and the LEDS velocity likely rapidly attenuated with distance away from the channel. At the site of overspill, a velocity of $10 \mathrm{~m} / \mathrm{s}$ correlates to a maximum dynamic pressure of $\sim 0.2$ to $0.25 \mathrm{kPa}$, assuming the previously estimated density of $\sim 4$ to $5 \mathrm{~kg} / \mathrm{m}^{3}$. These values represent upper estimates as the pre-PDC channel infill likely banked up on the western wall of the channel, so that the overspill height is overestimated. These pressures are consistent with lack of significant tree blowdown, as even minor blowdown requires 0.5-0.8 kPa of dynamic pressure (Valentine 1998), which at our estimated densities would require a minimum velocity of $\sim 14-16 \mathrm{~m} / \mathrm{s}$ to generate.

$V=\sqrt{2 g h}($ Equation 2)

Where $V=$ velocity $(\mathrm{m} / \mathrm{s}), \mathrm{g}=$ gravity $\left(\mathrm{m} / \mathrm{s}^{2}\right), h=$ height of barrier to overcome $(\mathrm{m})$.

Some of the standing trees within the village showed light blackening of the bark on the side facing the surge, and their leaves were killed, but the branches remained intact reflecting the low dynamic pressures. Buildings showed limited evidence of mechanical impact: tiles on overhanging parts of roofs facing the channel were blown off by the LEDS being deflected upwards as it hit the wall (Figure 7c). For only the tiles on the overhang to be lifted, the pressure upwards must exceed the weight of the tile in this location but not in other parts of the roof (BSI, 1996), which we calculate required dynamic pressure of 0.1 to $0.2 \mathrm{kPa}$. Similarly, low dynamic pressure values can be calculated for the concrete utility pole to remain upright $(<0.5 \mathrm{kPa})$ and a small number of palm trees to be beheaded but not felled ( $<0.5 \mathrm{kPa}$ : Jenkins et al., 2013). There was likely a rapid drop off in pressures as the LEDS moved laterally farther from the channel, with no evidence of elevated pressures beyond $40 \mathrm{~m}$. LEDS in Bronggang were therefore not very turbulent given the low dynamic pressures and limited lateral propagation.

Evidence for the thermal effects of the LEDS was complicated by the presence of fires (Figure 5), but a number of effects to objects away from the fires could be used to narrow down a likely LEDS temperature of 200 to $300{ }^{\circ} \mathrm{C}$ : i) Window glass cracked but did not melt (70 to $700{ }^{\circ} \mathrm{C}$ ); ii) Healthy vegetation dried and singed, but did not ignite $\left(100\right.$ to $\left.400{ }^{\circ} \mathrm{C}\right)$; iii) Casualties suffered deep burns to uncovered skin ( $>150^{\circ} \mathrm{C}$ : Baxter et al., 2017); iv) Acrylic roof sheets deformed ( $>160^{\circ} \mathrm{C}$ ) (Figure $7 \mathrm{~d}$ ); v) Thinner nylon clothes melted but did not auto-ignite (200 to $300^{\circ} \mathrm{C}$ ). This temperature range is low compared to some instances of LEDS recorded at other volcanoes (e.g., LEDS in the June 1997 
670 Soufrière Hills eruption likely reached temperatures over $400{ }^{\circ} \mathrm{C}$; Loughlin et al. 2002a), though 671 similar to LEDS temperatures estimated in the 1994 Merapi eruption (Voight and Davis 2000).

672 Possible reasons for the lower temperature LEDS in this eruption likely mirror the reasons for lower 673 temperature overspill deposits, as discussed in Section 3.2.4.

674 The multi-disciplinary analysis of the Merapi 2010 eruption was the first of its kind making use of

675

676

677

678

679

680

681

682

683

684

685

686

687

688

689

690

691

692

693

694

695

696

697

698

699

700 geological, engineering and medical expertise together to reconstruct PDC dynamics. The eruption also differed from prior eruptions because of the sheer number of social and professional media images of the impacts that became immediately available. These remotely sourced images, plus satellite imagery, provided a valuable source of additional information that could be evaluated to: i) infer conditions and impacts as close to the time of PDC inundation as possible, ii) assess impacts over the total PDC impacted area of $\sim 22 \mathrm{~km}^{2}$, and iii) identify locations where field studies should focus. We were able to apply the lessons learned from the remote and field assessment of Merapi's unconfined PDCs to make a similar assessment of unconfined PDCs produced by the Fuego 2018 eruption in Guatemala.

\section{$4 \quad$ The 2018 Volcán de Fuego eruption}

Unconfined PDCs during the Fuego 2018 eruption in Guatemala destroyed an estimated 750 buildings in areas within $8.5 \mathrm{~km}$ of the volcano and resulted in at least 332 people killed or missing (with independent estimates of up to 2,900 deaths) (Naismith et al. 2020). The Fuego eruption of 3 June 2018 began at 06:00 local time (UTC-6) with paroxysms from the summit vent and PDCs traveling down the western flanks, largely consistent with the volcano's previous eruptive history (Naismith et al. 2019, Pardini et al. 2019). Activity intensified by 12:00 local time, generating a series of PDCs that propagated over $11 \mathrm{~km}$ down Barranca Las Lajas to the southeast between 14:00 and 16:00 (Naismith et al. 2019). The flow volume could not be contained by the barranca and overspilled the eastern banks of the Las Lajas channel at $\sim 7 \mathrm{~km}$ from the summit at the site of La Reunión golf resort, which had been previously evacuated, as well as the western bank of the channel at $\sim 8 \mathrm{~km}$ from the summit, where the channel constricted and there was a sharp bend towards the east. This latter overspill inundated the village of San Miguel los Lotes (located at $\sim 9 \mathrm{~km}$ from the summit), which was still inhabited at the time (Flynn and Ramsey 2020). As the PDC struck on a Sunday, many people were congregated at church or at homes and were not working outside of the town. Further PDCs in the Barranca Las Lajas hampered rescue operations two days later on 5 June but remained contained within the channel. Fifty badly burnt casualties caught in dilute PDCs were admitted to 
701 hospital, with some urgently transferred by air for treatment in specialist hospitals in the USA and 702 Mexico.

703 A field assessment of deposits from the 2018 Fuego eruption in San Migues los Lotes, La Reunión, 704 and the adjacent channels was carried out in August 2018, $\sim 3$ months after the May eruption [by $705 \mathrm{SJC}$. The focus of the field visit was on geological deposits, but ancillary information on impacts was 706 collected where possible, mostly in the form of photographs and field notes. A health-focused assessment was undertaken in June 2018 at the invitation the Pan-American Health Organization (by PJB). As with Merapi, there were a large number of - sometimes graphic - images available from social and professional media in the hours, days and weeks following the June 2018 PDCs. We collected as many images as possible, broadly categorising them into deposits, impacts and casualties, and further cataloguing each image according to information it may provide regarding PDC dynamics such as velocity, dynamic pressure or temperature. We also used pre- (March 2018) and post-eruption (November 2018) Google Earth satellite imagery, and georeferenced high-resolution satellite images acquired in the days following the eruption and made available online (e.g., Digital Globe imagery acquired on June 7, 2018: White, 2018) to map pre-eruption building locations, and subsequent posteruption damage. We followed the damage categories applied by Jenkins et al. (2013) for Merapi: Totally Destroyed (TD) where the building was not visible in post-eruption images, Partially Damaged (PD) where some of the building structure remained and could be seen in post-eruption images, and No Visible Structural Damage (NVSD) for buildings that appeared unaffected in satellite imagery. A total of 125 TD, 35 PD and 95 NVSD buildings were observed across La Reunión golf resort (3 TD, 8 PD, 47 NVSD) and San Miguel Los Lotes (122 TD, 27 PD, 48 NVSD) (Figure 8). The later Google Earth imagery, acquired $\sim 5$ months after the eruption, showed that most roofing material (metal sheets) in San Miguel los Lotes had been scavenged from PD and NVSD buildings in the intervening months (Fig 8a). From satellite and media imagery of the two overspill locations, we were able to identify at least two types of unconfined PDC, and their impact:

1. Overspill flows, of variable speed, which contained large ( $>2 \mathrm{~m}$ diameter) boulders that caused non-uniform building damage, and were responsible for almost all buildings in the TD and PD categories at both locations, with media images indicating a small number of buildings may have been inundated without causing damage;

2. Low-Energy Detached Surges (LEDS), which for the most part caused little thermal or mechanical damage, resulting in primarily buildings in the NVSD category, even though they were still fatal for at least some of the victims caught in them. 


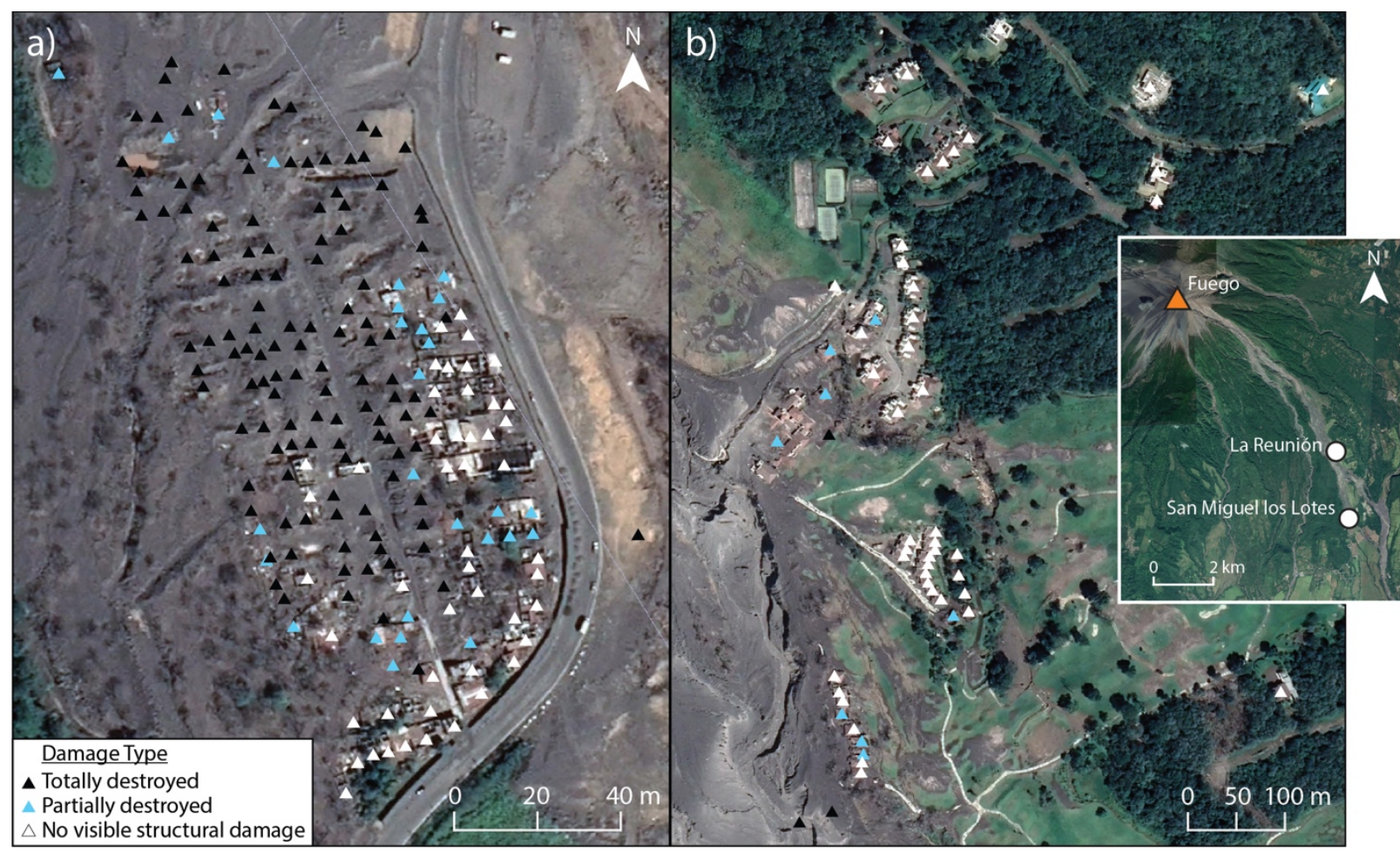

Figure 8: Remotely mapped building damage for the two main flow overspill locations of a) San Miguel los Lotes, and b) La Reunión golf resort, following the Fuego 2018 eruption. Google Earth satellite imagery from November 2018 is shown although we assessed damage using a range of remote sourced imagery. Inset shows locations relative to Fuego volcano.

\subsection{Impacts}

At La Reunión golf resort, the main club building was partially inundated with unconfined PDC deposits and appears to have obstructed the dense component of the PDC, with only isolated lobes of the dense flow extending downflow towards the southeast onto the golf course (Figure 9c). The main clubhouse sustained structural damage on the upflow side (Figure 9c), and some individual residences sustained partial damage from fires that caused roof collapse, but only three buildings were totally destroyed, two of which were less than $50 \mathrm{~m}$ from the channel edge (Figure 8b). Inside buildings, there was evidence of slow overspill flow inundation that left deposits of $80 \mathrm{~cm}$ or more, with associated surges that left deposits of a few centimetres (Figure 9b). Media images (22 June 2018) showed subsequent inundation of lahars and debris that left $\sim 50 \mathrm{~cm}$-thick deposits and moved chairs and tables: these could be distinguished from PDC deposits in media images by: i) the increased debris (e.g., branches, bricks) that they carried, ii) evidence of deposit surface remobilisation, iii) that they were clearly wet in comparison with photos of pristine PDC deposits, 
752 and iv) the correlation with mechanical impact above the flow (lahars not imparting any mechanical 753 impact above their flow surface: Figure 9a).

754 Approximately two-thirds of the northwestern area of the village of San Miguel Los Lotes was almost 755 totally destroyed by overbank PDCs on 3 June (Figure 8a), which contained large boulders many 756 metres in diameter inside an ash matrix and left massive, poorly sorted deposits up to 2 or more 757 metres deep (Figure 9d and e). A small number of buildings at the northern end of the town escaped 758 total destruction, and buildings at the edge of the zone of total destruction towards the south and 759 east of the town mostly suffered partial damage, but their structures were still identifiable on satellite 760 imagery (Figure 8a). The portion of the main road running along the south-east and east side of the 761 town (RN-14) was completely inundated, although access to the very southernmost part of the village 762 was maintained.

763 Most buildings at the golf course and at the far southern and eastern periphery of San Miguel Los 764 Lotes remained relatively intact with no damage visible in satellite imagery. Media images taken 765 during rescue operations show that people died in LEDS affected areas in San Miguel los Lotes where 766 there was little thermal or mechanical damage to buildings. However, the majority of casualties in 767 the village were buried inside the thick overbank PDC deposits that entered houses and buildings, creating issues to recover the bodies and correctly evaluate the human impact of the eruption. 


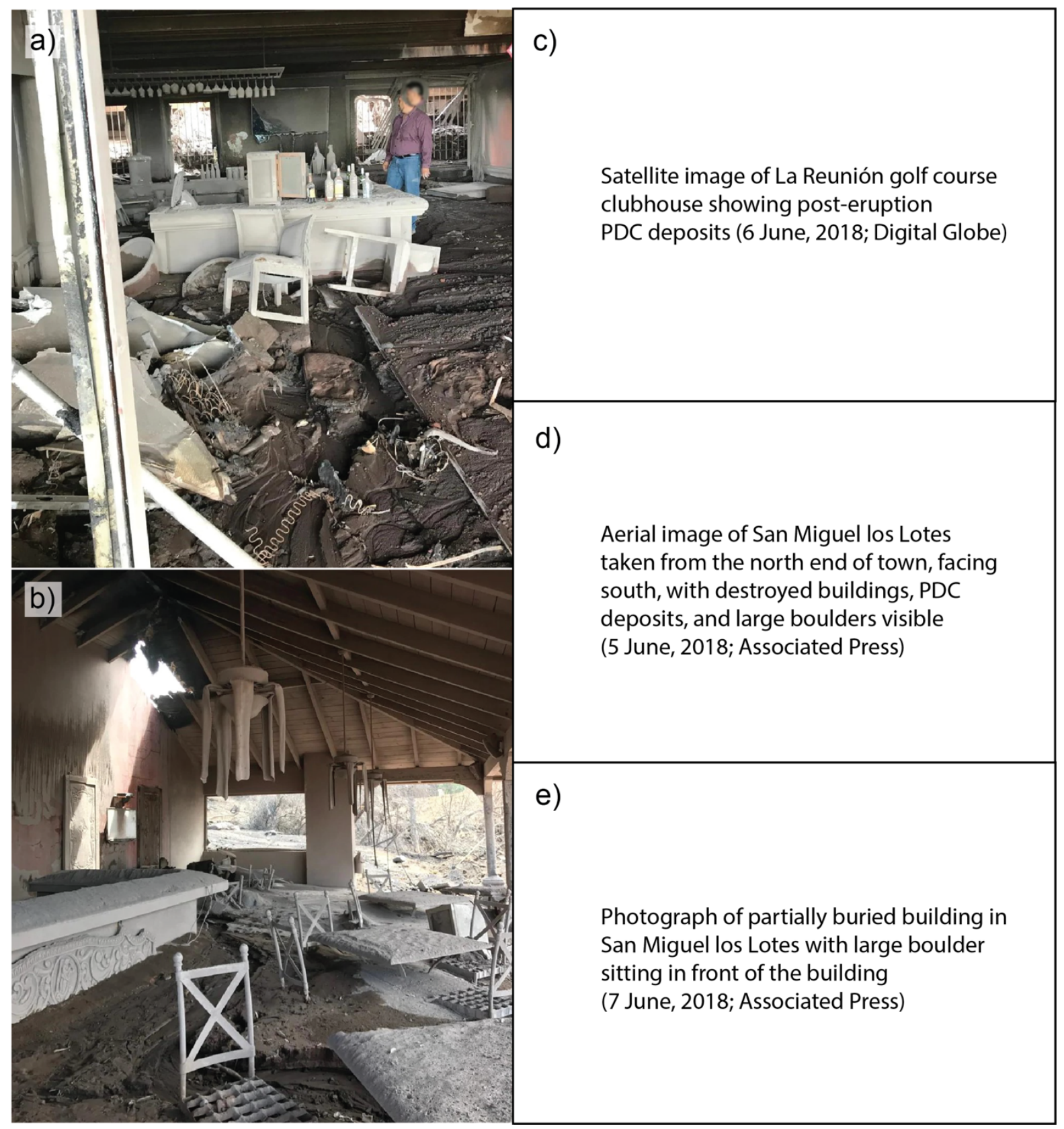

Figure 9: a) inside of La Reunión clubhouse building showing effect of LEDS (ash-covered bottles on counter) and post-eruption lahars (knocked over chairs) (22 June, 2018), b) inside of clubhouse building showing overspill deposits to chair height, LEDS deposits of a few centimetres on tables, isolated fire damage to roof, and ceiling fan melted due to radiant heat from overspill deposits (22 June, 2018); c) Digital Globe satellite imagery of La Reunión golf resort (acquired three days after impact on 6 June, 2018) showing partially inundated clubhouse building. Different shade of grey between left and right side of the buildings shows deposition areas of dense overspill flows (L) which were stopped by structures and LEDS (R) which were able to flow past; d) aerial photo of San Miguel los Lotes, facing south, showing fully destroyed northern end of town (bottom of frame) with large boulders, contrasted with mostly undamaged buildings at the south end of town (top left of frame) (AP, 5 June, 2018), e) partially buried building in San Miguel los Lotes with large boulder carried by dense overspill flows (AP, 7 June, 2018). (Reproduction rights for c-e to be purchased from the appropriate copyright holder upon article acceptance.) 


\subsection{Inferred dynamics}

The maximum height of the PDCs was not easy to determine from media images. There were a number of tall $(>10 \mathrm{~m})$ trees in both affected areas that appear singed by the PDC, implying a current height of more than $10 \mathrm{~m}$ as the PDC entered the town and golf resort. Media videos of the PDC flowing past a bridge in the adjacent channel just to the south of San Miguel los Lotes suggest that current heights maintained similar heights in the channel. However, trees in the southern half of San Miguel Los Lotes and towards the peripheries of impacted areas at La Reunión golf resort were not singed to their full height, with canopies still showing as green and unaffected in satellite imagery while the full height of buildings was affected. Thus, the total PDC height decreased from $>10 \mathrm{~m}$ to between 2 to $10 \mathrm{~m}$ as the flow slowed down and came to a stop.

At the golf resort, the energy of the overspill flows was low enough that they could be largely blocked by buildings, and where the flows entered buildings, they only moved objects such as chairs a few tens of centimetres away with the associated surges leaving countertop items such as bottles coated in ash but upright (Figure 9a). This suggests that both the dense and dilute PDC components were traveling at $\sim 1 \mathrm{~m} / \mathrm{s}$ (certainly less then $5 \mathrm{~m} / \mathrm{s}$ based on the categories outlined in Figure 1) with minimal dynamic pressures $(<0.2 \mathrm{kPa})$. LEDS at the golf resort maintained similarly low velocities and dynamic pressures, evidenced by their ability to fell only slim and very small (2-3 m height) trees or palms, but not to remove roof tiles or to move items located on tables inside buildings. Some media images showed wall and roof damage at the golf resort, and field investigation confirmed structural damage to the main clubhouse from PDCs, while most of this damage to other buildings seemed to be the result of post-eruption lahars (wall damage) and fire events (roof damage), rather than direct damage from PDCs (Figure 9b).

In San Miguel los Lotes, the overspill flows likely decreased in velocity and dynamic pressure as they moved south and east in order for the buildings in these parts of town to sustain minimal to no observable damage. The widespread destruction of most buildings at the northern part of the town along with a few surviving buildings of the same typology (Figure 8a) suggests that destruction of buildings was caused by a combination of dynamic pressure and missile damage from large clasts carried by the flows. Many large boulders of $2 \mathrm{~m}$ diameter or more can be seen in and near the north end of town in post-eruption photos (Figure 9d and e) and satellite imagery. LEDS in San Miguel Los Lotes appeared to have low velocity and dynamic pressure $(<0.5 \mathrm{kPa})$, evidenced by the fact that many trees (including palms) within the village remained standing and metal roof sheets remained attached to the roof framing after the event. 
816 Isolated fire damage could be seen in some of the buildings at the golf course and in San Miguel Los

817 Lotes, leading to partial or total roof collapse in places. It is not clear from remotely derived imagery

818 if isolated fires were the result of embers carried within the PDC, as at Merapi, or related to the heat

819 of the deposits. Flow deposits at Fuego contained large boulders, but field studies showed that most

820 of these boulders were not juvenile, and therefore unlikely to have provided a concentrated heat

821 source that may also have triggered fire.

822 Photos from the rescue operation in San Migues los Lotes show that the PDC deposits were hot 823 enough that it was necessary for responders to lay boards down to walk on in some locations, and 824 there were reports of responder's shoe soles melting (World Bank 2018). These suggest deposits of 825 at least $100^{\circ} \mathrm{C}$, but likely much higher. In one media photo from the interior of a golf course building, 826 chair bases and plastic ceiling fans were melted, and we infer this is the result of radiant heat from 827 the flow deposit rather than the heat associated with the surge (Figure 9b). For LEDS, media photos 828 from both the golf course and the town indicate relatively low temperatures for the most part 829 (maximum $100-200^{\circ} \mathrm{C}$ ). Fragile items such as plastic plant pots and bags are not deformed or melted, 830 and in available media images there is no evidence for cracked glasses and only very slight melting 831 to thin nylon clothing $\left(>70^{\circ} \mathrm{C}\right)$. Additionally, media images showed plants that remained alive, and 832 were not dried out, singed or charred by the passing LEDS. This suggests temperatures of around 100 $833{ }^{\circ} \mathrm{C}$ or less, significantly lower than in more proximal areas $(<5 \mathrm{~km})$, where photos from the field 834 studies show significant singing and burning of trees and coffee plants. However, by contrast, some media images showed casualties in a pugilistic attitude with clothing intact, indicating fourth degree 836 burns that have penetrated below the skin layer to involve the limb muscles (at least $200{ }^{\circ} \mathrm{C}$ ) (Baxter, 837 1990). Not all casualties displayed this attitude, despite wearing similar clothing (t-shirt and 838 trousers) and being affected by LEDS in the same town. Since there was no observed evidence of fires 839 near these casualties, the temperatures necessary to cause these injuries can be attributed to the 840 LEDS. The evidence from thermal effects therefore suggests that there was variability in temperature 841 and/or duration of the impact across the impacted area, reflecting the uneven inundation of PDCs 842 across the village area.

843 While remotely assessing impacts visible in satellite, aerial and media images in this case study was 844 valuable, access to photos and on-the-ground experience in the aftermath of the Fuego eruption provided vital detail that allowed us to confirm or refute inferences made from media images and 846 added information not visible in remote imagery. Ideally, remote and field approaches are combined, 847 with remote approaches providing information on the immediate post-impact situation and for areas 
that cannot be easily accessed as well as providing the larger scale overview, which can then be refined and ground-truthed with informed field visits that provide more detailed information, background and context. Studies relating impacts and PDC dynamics with the deposits provide an evidence base from which likely PDC dynamics and impacts can be forecast. This is particularly important for volcanoes where there are no data on past eruptions, or where the only data available are past deposits.

\section{Discussion and conclusions}

In this study, we reviewed the physical characteristics and devastating impact associated with unconfined PDCs. We identified four unconfined PDC end-member types: i) Fast overspill flow; ii) Slow overspill flow; iii) High energy surge; and iv) Low energy detached surge, all four of which were produced by the 2010 Merapi eruption, Indonesia. We used previously unpublished data on the deposits and impacts of slow overspill flows in Bakalan village, $12.6 \mathrm{~km}$ from the summit, and LEDS in Bronggang village, $13.5 \mathrm{~km}$ from the summit, to infer some key characteristics of their emplacement dynamics. Using the lessons learned from Merapi, we then applied the same approach using remotely sourced imagery (satellite images, social and professional media) and field studies to assess impacts and infer the dynamics of unconfined PDCs produced during the Fuego 2018 eruption. The deposits, impacts and dynamics associated with the unconfined slow overspill flows and low energy detached surges produced during the case study eruptions of Merapi and Fuego fall within the range of those observed or inferred in previously recorded events (Table 1 and Section 2). Broad conclusions can thus be drawn about the key characteristics and impacts of unconfined PDCs:

1. Destruction of buildings, vegetation and infrastructure is typically complete in the main path of fast overspill flows and high-energy surges;

2. A rapid attenuation in velocity at the peripheries of flow overspills and high-energy surges leads to reduced dynamic pressures and thus reduced mechanical impact and severity of damage. At the very peripheries of flows (slow overspill flow margin), deposits bank up against the sides of buildings or inundate the interior through open doors without causing any structural damage;

3. Low-energy detached surges are unique amongst the four unconfined PDC types in that they cause relatively little damage through dynamic pressures and leave little geological evidence; however, they are still mostly fatal because of the heat flux and should therefore be afforded the same consideration for hazard management planning as the unconfined dense flows and highenergy surges for which we may have more geological evidence; 
4. The temperature of unconfined PDCs can vary greatly between eruptions, as a function of the PDC volume, generation mechanism and transport path, as well as the presence of heat sinks such as wet vegetation;

5. General patterns of reduced or little damage in areas where dynamic pressures were relatively low were disrupted by isolated instances of total building damage as a result of fires or boulders/debris transported within the flow.

Table 1: The range of unconfined PDC characteristics and dynamics for each unconfined PDC type from previous eruptions following the studies reported in Section 1 and 2and this study. Values obtained for the four detailed study areas of the Merapi 2010 and Fuego 2018 eruptions are shown in brackets. Distances are straight-line and represent the shortest distance from impact site to summit or channel, and not necessarily the distance travelled.

\begin{tabular}{|c|c|c|c|c|c|c|}
\hline \multirow{2}{*}{$\begin{array}{l}\text { Deposit } \\
\text { thickness (at } \\
\text { impact sites) }\end{array}$} & \multicolumn{4}{|c|}{ Dynamics } & \multicolumn{2}{|c|}{ Distance to impact site } \\
\hline & Height & Velocity & $\begin{array}{l}\text { Dynamic } \\
\text { pressure }\end{array}$ & Temperature & $\begin{array}{l}\text { From } \\
\text { summit }\end{array}$ & From channel \\
\hline \multicolumn{7}{|c|}{ Fast overspill flow } \\
\hline $\begin{array}{l}\text { 10s of } \\
\text { centimetres a to } \\
\text { metres }^{c}\end{array}$ & - & $\begin{array}{l}30 \mathrm{~m} / \mathrm{s} \text { to } \\
60 \mathrm{~m} / \mathrm{s}\end{array}$ & $\begin{array}{l}\text { Up to } 100 \\
\mathrm{kPa} \text { proximal, } \\
15 \mathrm{kPa} \text { distal }\end{array}$ & Up to $>600^{\circ} \mathrm{Ca}$ & $5 \mathrm{~km}^{\mathrm{a}, \mathrm{c}}$ & $\begin{array}{l}600 \mathrm{~m}^{\mathrm{c}} \text { to } 800 \\
\mathrm{~m}^{\mathrm{a}}\end{array}$ \\
\hline \multicolumn{7}{|c|}{ Slow overspill flow margin } \\
\hline $\begin{array}{l}\text { Up to } 0.5 \mathrm{~m}^{\mathrm{e}} \\
\text { [Up to } \sim 2 \mathrm{~m}^{\mathrm{a}} \text {, } \\
\text { up to } \sim 3 \mathrm{~m}^{\mathrm{b}} \text { ] }\end{array}$ & $\begin{array}{l}2 \mathrm{~m}^{\mathrm{b}} \text { to } 10 \mathrm{~m}^{\mathrm{a}, \mathrm{b}} \\
{\left[10 \mathrm{~m}^{\mathrm{a}}, 2-10\right.} \\
\left.\mathrm{m}^{\mathrm{b}}\right]\end{array}$ & $\begin{array}{l}1 \mathrm{~m} / \mathrm{s}^{\mathrm{e}} \text { to } \\
2.5 \mathrm{~m} / \mathrm{s}^{\mathrm{a}} \\
{\left[\sim 2.5 \mathrm{~m} / \mathrm{s}^{\mathrm{a}},\right.} \\
\left.\sim 1 \mathrm{~m} / \mathrm{s}^{\mathrm{b}}\right]\end{array}$ & $\begin{array}{l}<0.5 \mathrm{kPa}^{\mathrm{b}} \text { to } 3 \\
\mathrm{kPa}^{\mathrm{a}, \mathrm{e}} \\
{\left[<3 \mathrm{kPa}^{\mathrm{a}},<0.5\right.} \\
\left.\mathrm{kPa}^{\mathrm{b}}\right]\end{array}$ & $\begin{array}{l}100^{\circ} \mathrm{C}^{\mathrm{a}} \text { to } 410 \\
{ }^{\circ} \mathrm{Ce} \\
{\left[100-200{ }^{\circ} \mathrm{C}^{\mathrm{a}},\right.} \\
\left.>100^{\circ} \mathrm{C}^{\mathrm{b}}\right]\end{array}$ & $\begin{array}{l}2 \mathrm{~km}^{\mathrm{e}} \text { to } 12.6 \\
\mathrm{~km}^{\mathrm{a}} \\
{\left[12.6 \mathrm{~km}^{\mathrm{a}}, 7\right.} \\
\left.\mathrm{km}^{\mathrm{b}}\right]\end{array}$ & $\begin{array}{l}200 \mathrm{~m}^{\mathrm{b}} \text { to } 300 \\
\mathrm{~m}^{\mathrm{a}} \\
{\left[300 \mathrm{~m}^{\mathrm{a}}, 200\right.} \\
\left.\mathrm{m}^{\mathrm{b}}\right]\end{array}$ \\
\hline \multicolumn{7}{|c|}{ High-energy surge } \\
\hline $\begin{array}{l}<20 \mathrm{~cm}^{\mathrm{h}} \text { to } \\
\text { Meters }\end{array}$ & - & $\begin{array}{l}50 \mathrm{~m} / \mathrm{s}^{\mathrm{i}} \text { to } \\
150 \mathrm{~m} / \mathrm{sg}^{2}\end{array}$ & $\begin{array}{l}<1 \mathrm{kPa}^{\mathrm{f}} \text { to } \\
>10 \mathrm{kPa}^{\mathrm{f}}\end{array}$ & $\begin{array}{l}120^{\circ} \mathrm{Cg} \text { to } 350 \\
{ }^{\circ} \mathrm{Ch}\end{array}$ & $\begin{array}{l}4 \mathrm{~km}^{\mathrm{h}} \text { to } 30 \\
\mathrm{kmg}\end{array}$ & $\begin{array}{l}\text { Up to } 0.8 \mathrm{~km}^{\mathrm{h}} \\
\text { or } \mathrm{n} / \mathrm{a} \text { (blast) }\end{array}$ \\
\hline \multicolumn{7}{|c|}{ Low-energy detached surge (LEDS) } \\
\hline $\begin{array}{l}\text { Few cme to } 20 \\
\mathrm{~cm}^{\mathrm{i}} \\
{\left[<4 \mathrm{~cm}^{\mathrm{a}} \text {, few }\right.} \\
\left.\mathrm{cm}^{\mathrm{b}}\right]\end{array}$ & $\begin{array}{l}2 \mathrm{~m}^{\mathrm{b}} \text { to } 10 \mathrm{~m}^{\mathrm{a}, \mathrm{b}} \\
{\left[8-10 \mathrm{~m}^{\mathrm{a}}, 2-10\right.} \\
\left.\mathrm{m}^{\mathrm{b}}\right]\end{array}$ & $\begin{array}{l}1 \mathrm{~m} / \mathrm{s}^{\mathrm{b}} \text { to } \\
10 \mathrm{~m} / \mathrm{s}^{\mathrm{a}} \\
{\left[<10 \mathrm{~m} / \mathrm{s}^{\mathrm{a}},\right.} \\
\left.\sim 1 \mathrm{~m} / \mathrm{s}^{\mathrm{b}}\right]\end{array}$ & $\begin{array}{l}<0.2 \mathrm{kPa}^{a} \text { to } 2 \\
\mathrm{kPa}^{2} \\
{\left[<0.2 \mathrm{kPa}^{2},\right.} \\
\left.<0.5 \mathrm{kPa}^{\mathrm{b}}\right]\end{array}$ & $\begin{array}{l}100^{\circ} \mathrm{Cb}^{\mathrm{b}} \text { to } \\
\sim 400^{\circ} \mathrm{Ce} \\
{\left[200-300^{\circ} \mathrm{Ca},\right.} \\
\left.100-200^{\circ} \mathrm{C}^{\mathrm{b}}\right]\end{array}$ & $\begin{array}{l}2.5 \mathrm{~km}^{\mathrm{e}} \text { to } \\
13.5 \mathrm{~km}^{\mathrm{a}} \\
{\left[13.5 \mathrm{~km}^{\mathrm{a}}, 8.5\right.} \\
\left.\mathrm{km}^{\mathrm{b}}\right]\end{array}$ & $\begin{array}{l}40 \mathrm{~m}^{\mathrm{i}} \text { to } 450 \\
\mathrm{~m}^{\mathrm{b}} \\
{\left[200 \mathrm{~m}^{\mathrm{a}}, 450\right.} \\
\left.\mathrm{m}^{\mathrm{b}}\right]\end{array}$ \\
\hline $\begin{array}{l}\text { aMerapi 2010, bf } \\
\text { hUnzen 1991, iN } \\
\text {-: Missing values }\end{array}$ & $\begin{array}{l}\text { go } 2018 \text {, cMera } \\
\text { api } 1994\end{array}$ & 006, dColim & 015, eSoufrière & ills 1997, fMour & & St. Helens 1980, \\
\hline
\end{tabular}

891 Unconfined PDCs exist on a spectrum of both concentration and velocity, which both contribute to 892 dynamic pressure, a key trait in determining the damage caused by a PDC. However, the temperature 
and duration of impact is also an important component in determining impact for the less energetic PDCs. These two factors affect the chance of survival and the probability of fire ignition. It is nearly impossible to disentangle the contribution of temperature and duration in determining thermal impact. Evidence from casualties in Bronggang affected by the LEDS of Merapi 2010, suggests an LEDS duration in the region of minutes (Baxter et al., 2017, Jenkins et al., 2013). Refining estimates of duration is difficult, especially if inferred from field and remote studies alone, although sophisticated numerical models that aim to recreate the physical processes underlying PDC generation and transport can offer some insight (e.g., Esposti Ongaro et al. 2020), as may controlled experiments (e.g., Mastrolorenzo et al. 2010).

The range of observed characteristics across different eruptions but within unconfined PDCs of the same type (Table 1) can be related to a few potential factors. The size of the magma batch and the volume of erupted material may affect PDC temperatures at their generation, leading ultimately to differences in source temperatures between eruptions, before PDCs become unconfined. The PDC generation mechanism appears to affect the temperature of ensuing PDCs: collapsing lava domes (e.g., Soufrière Hills 1997, Merapi 1994, 2006, 2010) are correlated with higher initial PDC temperatures than a sector collapse (e.g., Fuego 2018), and this appears to play a stronger role than distance from the volcano. For example, PDCs at the affected sites near Fuego appear to have been either similar or lower temperature despite being closer to the volcano $(\sim 8 \mathrm{~km})$ than the sites at Merapi $(\sim 13 \mathrm{~km})$.

The velocity (and therefore the dynamic pressure) of PDCs seems to be strongly influenced by the cause of unconfinement. Based on recorded examples, PDCs unconfined from inception (e.g., directed blast at Mt. Pelée 1902) and those that simply outrun their valley-confined, parent flows (e.g., highenergy surges at Unzen 1991) seem capable of maintaining their high velocities (>60 m/s), while those caused by channel bends or constrictions (e.g., slow overspills and LEDS at Merapi 1994 and 2010) often decrease in velocity drastically soon after leaving the channel to the speeds inferred in this study $(<10 \mathrm{~m} / \mathrm{s})$. Unconfined PDCs, despite their lower velocities, can maintain high mobility, flowing kilometres downstream after unconfinement (e.g., Merapi 2010, Fuego 2018) or even reforming confined flows when encountering a new channel (e.g., Soufrière Hills June 1997). As a general rule, LEDS are the slowest-moving (a few m/s) and most dilute $\left(<5 \mathrm{~kg} / \mathrm{m}^{3}\right)$ of the unconfined PDCs, resulting in the lowest dynamic pressures $(<0.5 \mathrm{kPa})$ and thus the least mechanical damage to buildings. LEDS deposits are typically no thicker than $20 \mathrm{~cm}$, with satellite imagery and field visits following the Fuego and Merapi eruptions showing that most of their deposits were on the order of 
925 a few centimetres and had already been washed away within as little as a few weeks. The ease with 926 which LEDS deposits can be eroded and washed away means that they are poorly preserved in the 927 geological record. However, in all previous cases where LEDS have inundated still inhabited areas, 928 they were hot enough to be deadly to their farthest extent.

929 LEDS are unique amongst the unconfined PDCs discussed here as they impart little mechanical impact and leave only very thin deposits but can still be fatal. A wide range of LEDS emplacement temperatures exists, with thermal impacts on plastics, vegetation and clothes suggesting relatively low temperatures of around 100-220 ${ }^{\circ} \mathrm{C}$ in San Miguel los Lotes, Fuego, $\sim 200-300{ }^{\circ} \mathrm{C}$ in Bronggang, Merapi, and $>400{ }^{\circ} \mathrm{C}$ in Streatham, Soufrière Hills. In Bronggang, less than $10 \%$ of the 59 people affected by the LEDS survived. It is impossible to determine the amount or percentage of casualties in San Miguel los Lotes resulting from LEDS even with an on-the-ground assessment due to the high amount of burial by the dense flows (resulting in extremely variable reporting on the death toll). Media images show that some of the deaths, especially in the southern end of town less affected by dense flows, were the result of people being caught in LEDS. In both the Merapi 2010 and Fuego 2018 eruptions, LEDS deaths occurred due to severe burns and inhalation both inside and outside buildings, evidenced by bodies found in a pugilistic attitude, with clothing often intact. Flow overspills were responsible for many more deaths in the Fuego eruption than at Merapi; a complex combination of political, cultural, economic, and demographic factors, unrelated to PDC dynamics or geology, likely played an important role. San Miguel los Lotes was significantly more populated than Bakalan and was not evacuated prior to the eruption, meaning that fatality in the northern part of the village highly affected by flows would have been near total. In Bakalan, there were only four or five casualties thanks to prior evacuation. Similarly, at La Reunión, loss of life was prevented by a full evacuation prior to the arrival of PDCs.

Fires following the inundation of PDC can cause more damage than the PDC itself, although with dense PDCs the evidence of damage can be buried. Widespread fire following the directed blast of Pelée 1902 incinerated the town of St. Pierre, leaving no evidence of the thermal impact of the PDC itself. In all recorded LEDS, localised fires were ignited and at Merapi, this could be attributed to embers (firebrands) carried within the LEDS (Jenkins et al., 2013). It is reasonable to infer that in situations with fewer firebrands present (e.g., fewer trees consumed in the surge path), the likelihood of building damage from LEDS may be lower. Building typology is also a factor affecting the level of 955 damage sustained during LEDS, with timber buildings much more likely to be damaged in a LEDS956 caused fire than masonry buildings. Considering these factors, fire damage resulting from LEDS is 
957 likely to be higher in dry areas and/or during dry seasons and in areas containing buildings made

958 from more flammable material. Conversely, it is possible that the potential for building damage from

959 LEDS could be diminished or discounted in arid unvegetated areas, where building types are less

960 flammable, if flammable items are removed prior to inundation, and/or during the rainy season or in

961 wet areas. However, the rapid inundation of multiple PDCs in a short amount of time (as at

962 Bronggang) can act to dry out wet vegetation or other sources of fuel priming it for ignition.

963

964

965

966

967

968

969

970

971

972

973

974

975

976

977

978

979

980

981

982

983

984

985

986

987

988

By their nature, unconfined PDCs are difficult to forecast because they inundate areas beyond the topographic lows that are typically given priority in volcanic hazard planning. As numerical models become more sophisticated (e.g., Esposti Ongaro et al. 2008, Kelfoun et al. 2017, Lube et al. 2020), they may be better able to recreate, and therefore forecast, the path and dynamics of unconfined PDCs. In the meantime, one approach in mitigation planning has been to apply a 'buffer' (e.g., Neri et al., 2015) around a PDC-prone channel to highlight threatened populations and infrastructure, with the aim of implementing long-term land-use or short-term proactive evacuation measures for communities close to topographic lows. The extent of this buffer is difficult to define, and is a function of the channel topography, PDC volume and local PDC mass flux/velocity as well as preceding events in the eruption sequence (e.g., the infilling by previous PDC deposits). For directed blasts, a buffer is clearly not appropriate because of their wide-reaching and topography-mantling nature, in these cases an energy cone model that defines distance from the summit may be useful. For those highenergy surges that are not unconfined from origin, e.g., Unzen 1991, this type of model is less useful as it is unable to identify locations of surge detachment. For overspill PDCs, we found they reach a maximum lateral distance of $800 \mathrm{~m}$ (Table 1) from the flowpath channel. However, we recognise that buffer extents are likely to be unique to the specific eruptions and require consideration of the topography, channel path and likely eruptive style. Reliance on geological deposits for defining buffers and potentially hazardous areas must be cognisant of the thinner deposits that reflect unconfined PDCs that cannot be preserved but are still deadly.

Volcanic hazard and risk assessment relies upon empirical data from past eruptions and their impacts. However, we are often limited in the amount of data that can be collected shortly after an event, while deposits and impacts are preserved, because of safety and access limitations. In this study, we have used lessons learned from remote and ground surveys of PDC dynamics following the Merapi 2010 eruption to provide a similar assessment for Fuego 2018. Remote assessment at Fuego using satellite imagery and media images to supplement a field study allowed for many similar determinations of PDC dynamics and resultant impacts as at Merapi. In both cases, through imagery 
or direct observation, building damage, extent of casualties, condition of vegetation, and state of materials like plastics and fabrics could be extrapolated into velocities, concentrations, dynamic pressures, temperatures, and the height of the associated PDCs. Personal familiarity with the affected area as well as presence on site allowed for more precise damage evaluation of buildings, as well as a more thorough record of geo-referenced photos than could be obtained through media images. Another vital piece of information provided by field studies is geological information. Detailed stratigraphic study and deposit analysis at Merapi was obtained over multiple field visits and these data, when combined with the impact assessment, were valuable for making inferences about PDC processes, whereas discussion of PDC dynamics at Fuego relied upon remote imagery and information from one field study, for which the focus was on deposits and not impacts. As shown at Merapi and Fuego, depending on the circumstances of the study, both remote and on-the-ground analysis serve a vital role in inferring the PDC characteristics that inform hazard models, mitigation, and risk assessment.

\section{CRediT authorship contribution statement}

SFJ devised the study. SFJ, SJC, PJB, and JCK performed fieldwork and/or in-person damage assessment. GAL and SFJ curated and compiled data. GAL and SFJ performed remote hazard assessment. GAL and SFJ wrote the first draft. GAL, SFJ, SJC, PJB, and JCK reviewed and edited the manuscript.

\section{Acknowledgements}

GAL and SFJ acknowledge funding from AXA and Singapore National Research Foundation (NRF2018NRF-NSFC003ES-010). This research was supported by the Earth Observatory of Singapore via its funding from the National Research Foundation Singapore and the Singapore Ministry of Education under the Research Centres of Excellence initiative. This work comprises EOS contribution number 371. SFJ, PJB and JCK are grateful for funding from the European Union (MIAVITA) and Agence Nationale de la Recherche (CASAVA). PJB acknowledges funding from the Pan American Health Organisation. SJC would like to acknowledge NSF RAPID grant \#1841852 and colleagues from the Fuego 2018 eruption crisis response team. The authors would like to acknowledge CVGHM, BPPTK, and INSIVUMEH for their cooperation and responses to the Merapi 2010 and Fuego 2018 eruptions. We are grateful to Nguyen Thi Nam Phuong for creating of the schematic portion of Figure 6. We would like to acknowledge an anonymous photographer for 
1019

1020

1021

1022

1023

1024

1025

1026

1027

1028

1029

1030

1031

1032

1033

1034

1035

1036

1037

1038

1039

1040

1041

1042

1043

1044

providing the non-credited photos used in Figure 9. We are grateful to Chai Min Wei who, in the weeks following the June 2018 Fuego eruption, collated many of the available media images.

\section{References}

Abdurachman, E.K., Bourdier, J.-L., Voight, B., 2000. Nuées ardentes of 22 November 1994 at Merapi volcano, Java, Indonesia. Journal of Volcanology and Geothermal Research 100, 345-361. https://doi.org/10.1016/S0377-0273(00)00144-X

Anderson, T., Flett, J.S., 1902. Preliminary report on the recent eruption of the Soufrière in St. Vincent, and of a visit to Mont Pelée, in Martinique. Proceedings of the Royal Society of London 70, 423445. https://doi.org/10.1098/rspl.1902.0042

Barcík, Š., Gašparík, M., Razumov, E.Y., 2014. EFFECT OF TEMPERATURE ON THE COLOR CHANGES OF WOOD DURING THERMAL MODIFICATION. Cell Chem Technol 49, 789-798.

Baxter, P.J., 1990. Medical effects of volcanic eruptions: I. Main causes of death and injury. Bull Volcanol 52, 532-544. https://doi.org/10.1007/BF00301534

Baxter, P.J., Boyle, R., Cole, P., Neri, A., Spence, R., Zuccaro, G., 2005. The impacts of pyroclastic surges on buildings at the eruption of the Soufrière Hills volcano, Montserrat. Bull Volcanol 67, 292313. https://doi.org/10.1007/s00445-004-0365-7

Baxter, P.J., Horwell, C.J., 2015. Impacts of Eruptions on Human Health, in: The Encyclopedia of Volcanoes. Elsevier, pp. 1035-1047. https://doi.org/10.1016/B978-0-12-385938-9.00060-2

Baxter, P.J., Jenkins, S., Seswandhana, R., Komorowski, J.-C., Dunn, K., Purser, D., Voight, B., Shelley, I., 2017. Human survival in volcanic eruptions: Thermal injuries in pyroclastic surges, their causes, prognosis and emergency management. Burns 43, 1051-1069. https://doi.org/10.1016/i.burns.2017.01.025

Belousov, A., Belousova, M., Hoblitt, R., Patia, H., 2020. The 1951 eruption of Mount Lamington, Papua New Guinea: Devastating directed blast triggered by small-scale edifice failure. Journal of $\begin{array}{llll}\text { Volcanology and Geothermal } & \text { Research 401, }\end{array}$ https://doi.org/10.1016/i.jvolgeores.2020.106947 
1045

1046

1047

1048

1049

1050

1051

1052

1053

1054

1055

1056

1057

1058

1059

1060

1061

1062

1063

1064

1065

1066

1067

1068

1069

1070

1071

Belousov, A., Voight, B., Belousova, M., 2007. Directed blasts and blast-generated pyroclastic density currents: a comparison of the Bezymianny 1956, Mount St Helens 1980, and Soufrière Hills, Montserrat 1997 eruptions and deposits. Bull Volcanol 69, 701. https://doi.org/10.1007/s00445-006-0109-y

Benage, M.C., Dufek, J., Mothes, P.A., 2016. Quantifying entrainment in pyroclastic density currents from the Tungurahua eruption, Ecuador: Integrating field proxies with numerical simulations. Geophysical Research Letters 43, 6932-6941. https://doi.org/10.1002/2016GL069527

Bourdier, J.L., Boudon, G., Gourgaud, A., 1989. Stratigraphy of the 1902 and 1929 nuée-ardente deposits, Mt. Pelée, Martinique. Journal of Volcanology and Geothermal Research 38, 77-96. https://doi.org/10.1016/0377-0273(89)90031-0

Breard, E.C.P., Lube, G., 2017. Inside pyroclastic density currents - uncovering the enigmatic flow structure and transport behaviour in large-scale experiments. Earth and Planetary Science Letters 458, 22-36. https://doi.org/10.1016/j.epsl.2016.10.016

Brosch, E., Lube, G., 2020. Spatiotemporal sediment transport and deposition processes in experimental dilute pyroclastic density currents. Journal of Volcanology and Geothermal Research 401, 106946. https://doi.org/10.1016/i.jvolgeores.2020.106946

Brown, R.J., Andrews, G.D.M., 2015. Chapter 36 - Deposits of Pyroclastic Density Currents, in: Sigurdsson, H. (Ed.), The Encyclopedia of Volcanoes (Second Edition). Academic Press, Amsterdam, pp. 631-648. https://doi.org/10.1016/B978-0-12-385938-9.00036-5

Brown, S.K., Jenkins, S.F., Sparks, R.S.J., Odbert, H., Auker, M.R., 2017. Volcanic fatalities database: analysis of volcanic threat with distance and victim classification. Journal of Applied Volcanology 6, 15. https://doi.org/10.1186/s13617-017-0067-4

BSI, B., 1996. 6399-1, Loading for buildings, in: Code of Practice for Dead and Imposed Loads. BSI, London, UK.

Bursik, M.I., Kurbatov, A.V., Sheridan, M.F., Woods, A.W., 1998. Transport and deposition in the May 18, 1980, Mount St. Helens blast flow. Geology 26, 155-158. https://doi.org/10.1130/00917613(1998)026<0155:TADITM>2.3.CO;2 
1072

1073

1074

1075

1076

1077

1078

1079

1080

1081

1082

1083

1084

1085

1086

1087

1088

1089

1090

1091

1092

1093

1094

1095

1096

1097

1098

1099

1100

Charbonnier, S.J., Germa, A., Connor, C.B., Gertisser, R., Preece, K., Komorowski, J.-C., Lavigne, F., Dixon, T., Connor, L., 2013. Evaluation of the impact of the 2010 pyroclastic density currents at Merapi volcano from high-resolution satellite imagery, field investigations and numerical simulations. Journal of Volcanology and Geothermal Research 261, 295-315. https://doi.org/10.1016/j.jvolgeores.2012.12.021

Charbonnier, S.J., Gertisser, R., 2008. Field observations and surface characteristics of pristine blockand-ash flow deposits from the 2006 eruption of Merapi Volcano, Java, Indonesia. Journal of Volcanology and Geothermal Research, Volcanic Flows and Falls 177, 971-982. https://doi.org/10.1016/i.jvolgeores.2008.07.008

Clarke, A.B., Voight, B., 2000. Pyroclastic current dynamic pressure from aerodynamics of tree or pole blow-down. Journal of Volcanology and Geothermal Research 100, 395-412. https://doi.org/10.1016/S0377-0273(00)00148-7

Cole, P.D., Calder, E.S., Sparks, R.S.J., Clarke, A.B., Druitt, T.H., Young, S.R., Herd, R.A., Harford, C.L., Norton, G.E., 2002. Deposits from dome-collapse and fountain-collapse pyroclastic flows at Soufrière Hills Volcano, Montserrat. Geological Society, London, Memoirs 21, 231-262. https://doi.org/10.1144/GSL.MEM.2002.021.01.11

Cole, P.D., Neri, A., Baxter, P.J., 2015. Chapter 54 - Hazards from Pyroclastic Density Currents, in: Sigurdsson, H. (Ed.), The Encyclopedia of Volcanoes (Second Edition). Academic Press, Amsterdam, pp. 943-956. https://doi.org/10.1016/B978-0-12-385938-9.00054-7

Cooper, M.J.M., 2018. The Mt. Unzen Disaster: A Terrible Learning Experience, in: Chakraborty, A., Mokudai, K., Cooper, M., Watanabe, M., Chakraborty, S. (Eds.), Natural Heritage of Japan, Geoheritage, Geoparks and Geotourism. Springer International Publishing, Cham, pp. 131-142. https://doi.org/10.1007/978-3-319-61896-8 12

Cronin, S.J., Lube, G., Dayudi, D.S., Sumarti, S., Subrandiyo, S., Surono, 2013. Insights into the OctoberNovember 2010 Gunung Merapi eruption (Central Java, Indonesia) from the stratigraphy, volume and characteristics of its pyroclastic deposits. Journal of Volcanology and Geothermal Research, Merapi eruption 261, 244-259. https://doi.org/10.1016/i.jvolgeores.2013.01.005

Dellino, P., Büttner, R., Dioguardi, F., Doronzo, D.M., La Volpe, L., Mele, D., Sonder, I., Sulpizio, R., Zimanowski, B., 2010. Experimental evidence links volcanic particle characteristics to 
pyroclastic flow hazard. Earth and Planetary Science Letters 295, 314-320. https://doi.org/10.1016/i.epsl.2010.04.022

Druitt, T.H., Calder, E.S., Cole, P.D., Hoblitt, R.P., Loughlin, S.C., Norton, G.E., Ritchie, L.J., Sparks, R.S.J., Voight, B., 2002. Small-volume, highly mobile pyroclastic flows formed by rapid sedimentation from pyroclastic surges at Soufrière Hills Volcano, Montserrat: an important volcanic hazard. Geological Society, London, Memoirs 21, 263-279. https://doi.org/10.1144/GSL.MEM.2002.021.01.12

Esposti Ongaro, T., Clarke, A.B., Neri, A., Voight, B., Widiwijayanti, C., 2008. Fluid dynamics of the 1997 Boxing Day volcanic blast on Montserrat, West Indies. Journal of Geophysical Research: Solid Earth 113. https://doi.org/10.1029/2006]B004898

Esposti Ongaro, T., Clarke, A.B., Voight, B., Neri, A., Widiwijayanti, C., 2012. Multiphase flow dynamics of pyroclastic density currents during the May 18, 1980 lateral blast of Mount St. Helens. Journal of Geophysical Research: Solid Earth 117. https://doi.org/10.1029/2011JB009081

Esposti Ongaro, T., Komorowski, J.-C., Legendre, Y., Neri, A., 2020. Modelling pyroclastic density currents from a subplinian eruption at La Soufrière de Guadeloupe (West Indies, France). Bull Volcanol 82, 76. https://doi.org/10.1007/s00445-020-01411-6

Fisher, R.V., Smith, A.L., Roobol, M.J., 1980. Destruction of St. Pierre, Martinique, by ash-cloud surges, May 8 and 20, 1902. Geology 8, 472-476. https://doi.org/10.1130/00917613(1980)8<472:DOSPMB>2.0.C0;2

Flynn, I.T.W., Ramsey, M.S., 2020. Pyroclastic Density Current Hazard Assessment and Modeling Uncertainties for Fuego Volcano, Guatemala. Remote Sensing 12, 2790. https://doi.org/10.3390/rs12172790

Fujii, T., Nakada, S., 1999. The 15 September 1991 pyroclastic flows at Unzen Volcano žJapan/: a flow model for associated ash-cloud surges 14.

Gertisser, R., Cassidy, N.J., Charbonnier, S.J., Nuzzo, L., Preece, K., 2012. Overbank block-and-ash flow deposits and the impact of valley-derived, unconfined flows on populated areas at Merapi volcano, Java, Indonesia. Nat Hazards 60, 623-648. https://doi.org/10.1007/s11069-011$\underline{0044-X}$ 
Gueugneau, V., Kelfoun, K., Charbonnier, S., Germa, A., Carazzo, G., 2020. Dynamics and Impacts of the May 8th, 1902 Pyroclastic Current at Mount Pelée (Martinique): New Insights From Numerical Modeling. Front. Earth Sci. 8. https://doi.org/10.3389/feart.2020.00279

Hovey, E.O., 1904. The 1902-1903 Eruptions of Mont Pelé, Martinique and the Soufrière, St. Vincent. Brothers Hollinek.

Jenkins, S., Komorowski, J.-C., Baxter, P.J., Spence, R., Picquout, A., Lavigne, F., Surono, 2013. The Merapi 2010 eruption: An interdisciplinary impact assessment methodology for studying pyroclastic density current dynamics. Journal of Volcanology and Geothermal Research 261, 316-329. https://doi.org/10.1016/j.jvolgeores.2013.02.012

Jenkins, S.F., Komorowski, J.-C., Baxter, P.J., Charbonnier, S.J., Cholik, N., Surono, 2016. The Devastating Impact of the 2010 Eruption of Merapi Volcano, Indonesia, in: Duarte, J.C., Schellart, W.P. (Eds.), Geophysical Monograph Series. John Wiley \& Sons, Inc., Hoboken, NJ, USA, pp. 259-269. https://doi.org/10.1002/9781119054146.ch12

Kelfoun, K., Gueugneau, V., Komorowski, J.-C., Aisyah, N., Cholik, N., Merciecca, C., 2017. Simulation of block-and-ash flows and ash-cloud surges of the 2010 eruption of Merapi volcano with a twolayer model. Journal of Geophysical Research: Solid Earth 122, 4277-4292. https://doi.org/10.1002/2017JB013981

Kelfoun, K., Legros, F., Gourgaud, A., 2000. A statistical study of trees damaged by the 22 November 1994 eruption of Merapi volcano (Java, Indonesia): relationships between ash-cloud surges and block-and-ash flows. Journal of Volcanology and Geothermal Research 100, 379-393. https://doi.org/10.1016/S0377-0273(00)00147-5

Komorowski, J.-C., Jenkins, S., Baxter, P.J., Picquout, A., Lavigne, F., Charbonnier, S., Gertisser, R., Preece, K., Cholik, N., Budi-Santoso, A., Surono, 2013. Paroxysmal dome explosion during the Merapi 2010 eruption: Processes and facies relationships of associated high-energy pyroclastic density currents. Journal of Volcanology and Geothermal Research 261, 260-294. https://doi.org/10.1016/i.jvolgeores.2013.01.007

Lacroix, A., 1904. La Montagne Pelee et ses eruptions. Masson. 
Lavigne, F., Komorowski, J.-C., Jenkins, S., Baxter, P., Vidal, C., Mei, E.T.W., Picquout, A., Grancher, D., Brunstein, D., N. C., 2011. Satellite Remote-sensing and Field Analysis of Casualties and Damage Caused by the 2010 eruption of Merapi Volcano Indonesia. Remote Sensing, natural hazards and environmental change, Singapore.

Loughlin, S.C., Baxter, P.J., Aspinall, W.P., Darroux, B., Harford, C.L., Miller, A.D., 2002a. Eyewitness accounts of the 25 June 1997 pyroclastic flows and surges at Soufrière Hills Volcano, Montserrat, and implications for disaster mitigation. Geological Society, London, Memoirs 21, 211-230. https://doi.org/10.1144/GSL.MEM.2002.021.01.10

Loughlin, S.C., Calder, E.S., Clarke, A., Cole, P.D., Luckett, R., Mangan, M.T., Pyle, D.M., Sparks, R.S.J., Voight, B., Watts, R.B., 2002b. Pyroclastic flows and surges generated by the 25 June 1997 dome collapse, Soufrière Hills Volcano, Montserrat. Geological Society, London, Memoirs 21, 191209. https://doi.org/10.1144/GSL.MEM.2002.021.01.09

Lube, G., Breard, E.C.P., Cronin, S.J., Jones, J., 2015. Synthesizing large-scale pyroclastic flows: Experimental design, scaling, and first results from PELE. Journal of Geophysical Research: Solid Earth 120, 1487-1502. https://doi.org/10.1002/2014JB011666

Lube, G., Breard, E.C.P., Esposti-Ongaro, T., Dufek, J., Brand, B., 2020. Multiphase flow behaviour and hazard prediction of pyroclastic density currents. Nature Reviews Earth \& Environment 1, 348-365. https://doi.org/10.1038/s43017-020-0064-8

Macorps, E., Charbonnier, S.J., Varley, N.R., Capra, L., Atlas, Z., Cabré, J., 2018. Stratigraphy, sedimentology and inferred flow dynamics from the July 2015 block-and-ash flow deposits at Volcán de Colima, Mexico. Journal of Volcanology and Geothermal Research 349, 99-116. https://doi.org/10.1016/i.jvolgeores.2017.09.025

Mastrolorenzo, G., Petrone, P., Pappalardo, L., Guarino, F.M., 2010. Lethal Thermal Impact at Periphery of Pyroclastic Surges: Evidences at Pompeii. PLOS ONE 5, e11127. https://doi.org/10.1371/journal.pone.0011127

Miyahara, T., Endo, K., Tohno, I., Chiba, T., Iso, N., Senda, K., Shinkawa, K., Yasui, M., Komori, J., Ohno, M., 1992. Eruptive products of the 1991 Unzen-Hugendake eruption (1). Proc. Inst. Nat. Sci. 27, 71-80. 
Moore, J.G., Melson, W.G., 1969. Nuées Ardentes of the 1968 Eruption of Mayon Volcano, Philippines. Bull Volcanol 33, 600-620. https://doi.org/10.1007/BF02596528

Naismith, A., Armijos, M.T., Escobar, E.A.B., Chigna, W., Watson, I.M., 2020. Fireside tales: understanding experiences of previous eruptions and factors influencing the decision to evacuate from activity of Volcán de Fuego. Volcanica 3, 205-226. https://doi.org/10.30909/vol.03.02.205226

Naismith, A.K., Matthew Watson, I., Escobar-Wolf, R., Chigna, G., Thomas, H., Coppola, D., Chun, C., 2019. Eruption frequency patterns through time for the current (1999-2018) activity cycle at Volcán de Fuego derived from remote sensing data: Evidence for an accelerating cycle of explosive paroxysms and potential implications of eruptive activity. Journal of Volcanology and Geothermal Research 371, 206-219. https://doi.org/10.1016/i.jvolgeores.2019.01.001

Nakada, S., Fujii, T., 1993. Preliminary report on the activity at Unzen Volcano (Japan), November 1990-November 1991: Dacite lava domes and pyroclastic flows. Journal of Volcanology and Geothermal Research 54, 319-333. https://doi.org/10.1016/0377-0273(93)90070-8

Neri, A., Esposti Ongaro, T., Voight, B., Widiwijayanti, C., 2015. Pyroclastic Density Current Hazards and Risk, in: Volcanic Hazards, Risks and Disasters. pp. 109-140. https://doi.org/10.1016/B978-0-12-396453-3.00005-8

Neri, A., Ongaro, T.E., Macedonio, G., Gidaspow, D., 2003. Multiparticle simulation of collapsing volcanic columns and pyroclastic flow. Journal of Geophysical Research: Solid Earth 108. https://doi.org/10.1029/2001JB000508

Pallister, J.S., Schneider, D.J., Griswold, J.P., Keeler, R.H., Burton, W.C., Noyles, C., Newhall, C.G., Ratdomopurbo, A., 2013. Merapi 2010 eruption-Chronology and extrusion rates monitored with satellite radar and used in eruption forecasting. Journal of Volcanology and Geothermal Research, Merapi eruption 261, 144-152. https://doi.org/10.1016/i.jvolgeores.2012.07.012

Pardini, F., Queißer, M., Naismith, A., Watson, I.M., Clarisse, L., Burton, M.R., 2019. Initial constraints on triggering mechanisms of the eruption of Fuego volcano (Guatemala) from 3 June 2018 using IASI satellite data. Journal of Volcanology and Geothermal Research 376, 54-61. https://doi.org/10.1016/i.jvolgeores.2019.03.014 
1212 Pensa, A., Capra, L., Giordano, G., 2019. Ash clouds temperature estimation. Implication on dilute and concentrated PDCs coupling and topography confinement. Sci Rep 9, 5657. https://doi.org/10.1038/s41598-019-42035-x

Pensa, A., Capra, L., Giordano, G., Corrado, S., 2018. Emplacement temperature estimation of the 2015 dome collapse of Volcán de Colima as key proxy for flow dynamics of confined and unconfined pyroclastic density currents. Journal of Volcanology and Geothermal Research 357, 321-338. https://doi.org/10.1016/i.jvolgeores.2018.05.010

Rosi, M., Principe, C., Vecci, R., 1993. The 1631 Vesuvius eruption. A reconstruction based on historical and stratigraphical data. Journal of Volcanology and Geothermal Research, Mount Vesuvius 58, 151-182. https://doi.org/10.1016/0377-0273(93)90106-2

Sulpizio, R., Dellino, P., 2008. Chapter 2 Sedimentology, Depositional Mechanisms and Pulsating Behaviour of Pyroclastic Density Currents, in: Gottsmann, J., Martí, J. (Eds.), Developments in Volcanology, Caldera Volcanism: Analysis, Modelling and Response. Elsevier, pp. 57-96. https://doi.org/10.1016/S1871-644X(07)00002-2

Surono, Jousset, P., Pallister, J., Boichu, M., Buongiorno, M.F., Budisantoso, A., Costa, F., Andreastuti, S., Prata, F., Schneider, D., Clarisse, L., Humaida, H., Sumarti, S., Bignami, C., Griswold, J., Carn, S., Oppenheimer, C., Lavigne, F., 2012. The 2010 explosive eruption of Java's Merapi volcano-A '100-year' event. Journal of Volcanology and Geothermal Research 241-242, 121-135. https://doi.org/10.1016/i.jvolgeores.2012.06.018

Trolese, M., Giordano, G., Komorowski, J.-C., Jenkins, S.F., Baxter, P.J., Cholik, N., Raditya, P., Corrado, S., 2018. Very rapid cooling of the energetic pyroclastic density currents associated with the 5 November 2010 Merapi eruption (Indonesia). Journal of Volcanology and Geothermal Research 358,1-12. https://doi.org/10.1016/i.jvolgeores.2018.06.004

Valentine, G.A., 1998. Damage to structures by pyroclastic flows and surges, inferred from nuclear weapons effects. J Volcanol Geotherm Res 87, 117-140.

Valentine, G.A., Wohletz, K.H., 1989. Numerical models of Plinian eruption columns and pyroclastic flows. Journal of Geophysical Research: Solid Earth 94, 1867-1887. https://doi.org/10.1029/JB094iB02p01867 
1240 Voight, B., Constantine, E.K., Siswowidjoyo, S., Torley, R., 2000. Historical eruptions of Merapi Volcano, Central Java, Indonesia, 1768-1998. Journal of Volcanology and Geothermal Research 100, 69-138. https://doi.org/10.1016/S0377-0273(00)00134-7

Voight, B., Davis, M.J., 2000. Emplacement temperatures of the November 22, 1994 nuée ardente deposits, Merapi Volcano, Java. Journal of Volcanology and Geothermal Research 100, 371-377. https://doi.org/10.1016/S0377-0273(00)00146-3

White, N., 2018. Shocking satellite photos show entire towns obliterated after Guatemala's “Volcano of Fire" buried them in tons of ash that crushed hundreds of homes and burned 300 people alive. Mail Online.

Wibowo, H.E., Purnama Edra, A., Harijoko, A., Anggara, F., 2018. Emplacement Temperature of the Overbank and Dilute-Detached Pyroclastic Density Currents of Merapi 5 November 2010 Events using Reflectance Analysis of Associated Charcoal. J. Appl. Geol. 3, 41. https://doi.org/10.22146/jag.42445

World Bank, 2018. June 3, 2018 Volcán de Fuego Guatemala Eruption Global Rapid Post Disaster Damage Estimation Grade Report (Global Rapid Post Disaster Damage Estimation (GRADE) Report No. AUS000903).

Yamamoto, T., Takarada, S., Suto, S., 1993. Pyroclastic flows from the 1991 eruption of Unzen volcano, Japan. Bull Volcanol 55, 166-175. https://doi.org/10.1007/BF00301514 